\title{
MENINGITE MENINGOCÓCICA NO MUNICÍPIO DE SÃO PAULO NO PERÍODO DE 1968 - 1974 ASPECTOS EPIDEMIOLÓGICOS
}

Monografia apresentada à Faculdado do Saúde Pública da Universidade de São Paulo para obtenção de grau de Mestre em Saúde Pública. 
APRESENTAÇÃ

1 - INTRODUÇÃO 3

II - OBJETIVD DO TRABALHO 7

III - REVISÃ̃ BIBLIOGRAFILA SOBRE VACINAÇÃD ANTIMENIN GOCÓCICA

IV - SITUAÇÃ DA MENINGITE MENINGOĆ́CICA ND BRASIL E NO MUNICIPIO DE SĂD PAULO

V - MATERIAL E MÉTDDOS

VI - RESULTADOS 36

1 - Meningite meningocócica e meningites por causa indeterminada

2 - Distribuição cronológica dos casos 41

3 - Distribuição geográfica dos casos 46

4 - Distribuiçãa dos casos segundo a ldade 50

5 - Distribuiçãa dos casos segundo a sexa 56

6 - Letalidade

6.1 Distribuição cronológica da letalldade 57

6.2 Distribuição da letalidade segunda a 57 idade

6.3 Distribuição da letalidade segundo o sexo

VII - DISCUSSÃO

1 - Eclosão e duração da epidemia 62

2 - Meningites meningocócicas e meningites por causa indeterminada

3 - Distribuição cronológica dos casos 67

4 - Distribuição geográfica dos casos 68

5 - Distribuição dos casos segunda a idade 72

6 - Distribuição dos casos segundo o sexo 74

7 - Distribuição cronológica da letalidade 76

8 - Distribujição da letalidade segunda a

9 - Distribuiçãa da letalidade segundo 0
sexa

VIII - CONCLUSOES

SUMÁRIO EM PORTUGUEES

SUMMARY 82

IX - REFERÊNCIAS BIBLIOGRÁFICAS 
A Idéla deste estuda nasceu ex um seminário sobre meningi te meningocócica que realizamos, com um grupo de coleges, em maio de 1973, para a disciplina Epidemiologia das Moléstias Transmiasi veis I, no Curso de Saúde Pública para graduadas da Faculdade de Saúde Pública de São Paulo.

Neg8a ocasião tivemos oportunidade de coletar a tabular dados de epidemia de meningite meningocócica que atingia a área da Grande São Paulo. Pudemos sentir a magnitude do problema a a con tribuição que um estudo epidemiológico poderia trazer aos aanita ristes.

Para a elaboração do trabalho foi fundamental a eatágio que realizamos na Secção de Epidemiologia da Diviaño Ragional de Saúde da Grande São Paulo a no Instituto Adolfo Lutz.

A orientação de mestrado coube ao Professor Vitório Barbo 8a, do Departamento de Epidemiologia da Faculdade de Saúde Pública de 5ão Paulo, a quem expressamos nossos agradecimentos pelo inte resee e orientação segura que nos proporcionou. Agradecemos tambám a tados aqueles que nos auxillaram com seus esclarecimentos a cam seu apoio. 


\section{I - INTRODULÃD}

A meningite meningocócica e a meningocemia eão complicações pouco frequenteg (20)(71) da infecção meningocáclca, determinada por uma bactéria Gram negativa da família das Nelsseriaceae-Neisse ria meningitidis, também cognominada Neisseria intracellularis, Diplococcus intracellularis meningitidis $\theta$, mais usualmente, menin gococo. (14)(71). A ação patogênica da bactéria é determinada por uma endotoxina lipopolissacarida (21)(73) que constitui um dos quatro principais componentes identificados na sua parede celular extérna. Admite-se que a eliminaçãa dessa endatoxina far-se-ia du rante a multiplicação bacteriana. Estudas recentes de Devoe e Gilchrist (18) (1973), através da microscopia eletrônica, relacio nam essa eliminação à formação e despreendimento de "bolhas" na pa rede celular por evaginação de sua camada mais externa, o que se observa nas culturas de mais crescimento bacteriano. A análise bioquímica dessas bolhas celulares. revelou a presença de endotaxi nas.

0 meningococo invade o organismo de seu hospedeiro, o homem, e instala-se no nasofaringe, causando ou não um processo inflamató rio das vias aéreas superiores. Usualmente permanece no local de forma essintomática durante períados variáveis de dias a semanas $(12)(20)(71)$. Esses portadores passivos canstituem as principais transmissores da moléstia $(12)(20)(71)$. Com menor frequência e por razões ainda não esclarecidas, a bactéria dissemina-se pela 
corrente sanguinea determinando quadros de bacteriemia(meningococe mia) ou de localização focal principalmente no sistema nervoso cen tral (meningite meningocócica).

A doença meningocócica tem importância em Saúde Pública em razão desses quadros de meningite e meningacacemia e pela passibi lidade de sua ocorrencia sob forma epidêmica.

A letalidade por meningite meningocócica na era anterior aos quimioterápicos e antibióticos ultrapassava cinquenta por cento dos casos $(11)(12)(20)$, e atualmente no municipio de São Paulo, se si tua em torno de aito por cento.

A letalidade por meningococemia no municipio de São Paulo ainda é de cinquenta e um por cento dos casos.

Podem causar também graves seqbelas, como alterações trófí cas mutilantes de tecidos moles, retardos mentais em grau variável, paralisias de natureza diversa, hidrocefalia, abcessas cerebrais, coleções subdurais, defeitos na audição, disfunção cerébral mínima. (19).

Diament (19) refere uma pesquisa de Trale, que observanda num período de 3 a 27 anos 327 pacientes que tiveram meningite me ningocócica na infância, verificou uma incidência de graves sequé las em $41 \%$ dos casos no grupo anterior ao emprego de quimiaterápi cos e antibióticos, e 17\% na grupo beneficiado cam essa medicaçãa. 
Não dispomos de estatísticas para avaliar o problema em nos so meio (19). A identificaçãa das seqbelas médias e leves exigi ria o seguimento do daente durante um certo períado, medida de di fícil execução no momento.

A moléstia causa graves prejuizos econômicos, levando-se em conta não só os gastos hospitalares durante o tratamento do doente (em média 3.000 cruzeiros por doente) (*), como as relativos a tratamento das seqlelas e à aquisição dos anlibióticos ou quiming terápicos utilizados profilaticamente no tratamento de possíveis portadores.

Alguns fundamentos epidemiológicos tornam difícil a contro le da doença meningocócica pelas autoridades sanitárias:

- Alta infectividade do agente etialógico.

- Facilidade de transmissão por via respiratória, pelo contato di reto com as secreções do nariz e garganta dos individuos infec tados ou através das gotículas de Flagge expelidas por esses in dividuos. A transmissão indireta através de fômites é de impoI tância discutível, pois o meningo:oco é muito sensível às varia ções de temperatura $\mathrm{e}$ ao dessecamento.

- A dificultade de identificação para tratamento adequado de ca sos clinicos que se assemelham a uma rinofaringite de outra etí ologia, assim como ne portadores passivos (12)(20)(71). Drticoni, Bauclier, Mattei, Gray e Glar (12), entre outros, admil.em mesmo

(*) Informação prestada pelo Dr。 Carlos de Oliveira Bastos, rDire tor do Hospital Emílio Ribas, ro Curso sobre meningite meningocócica realizado em julho de 1974, sob a patrocinio da Orga nização Panamericana ue Saúde. 
que se poderia prever a eclosão de uma epidemia sempre que a taxa de portadores subisse acima de 5\% de populaçãa. Gover (12), estudando militares em treinamento na Inglaterra durante a Prí meira Guerra Mundial, verificou que quando essa taxa de portado res atingia 20\% ocorria um surto epidêmico. No entanto, Rake(1934), Dudley e Brennan (1934), Phair, Scholembach e Root (1944) (65), Maxcy (1937), Finland e Dingle (1942), Aycak e Mueller (1950)(12) (58), puzeram em dúvida essa correlação direta entre a elevação do número de portadores e a maior incidência da meningite menín gocócica.

Mais recentemente (1974) Artenstein e colaboradores (9) realiza ram pesquisas mensais de portadares em sete campos de treinamen to militar, e não encontraram essa correlação entre o aumento de portadares e a maior incidência da moléstia, seja para um de terminado sorogrupo, seja em geral. Concluem Artenstein e cola boradores que "as pesquisas de rotina de portadores de meningo coco não forneceram qualquer informação que permitisse um prog nóstico sobre a incidência da moléstia e portanto foram de pou co valor nos programas de controle". Ds autores enfatizam a im portância, nesses programas, da rápida notificação dos casos clínicos.

Em nossa meio nenhuma pesquisa foi feita no sentida de esclare cer essa hipótese.

Considerando-ge esses fundamentas epidemiológicas e as tra balhos de Kolmer e colaboradores (1918) (30), Heist e calabora dores (1922) (41) e liGolidschneider e colaboradares (1969) (30) que levantaram e confirmaram a hipótese de que a doença meningo cócica sistêmica estaria mai̊ relacionada à susceptibilidade do homem por falta de anticorpos humorais contra o meningococo, a melhor medida profilática seria a imunização artificial da popㅆ lação suscetível cam uma vacina de eficácia comprovada, que de terminasse jroteção à infecção causada pelos diversos sorogru pos de meningoçaco. 
Em abril de 1971 a caeficiente de marbidade da meningite me ningocócica no municipio de São Paulo apresentou um aumento que se acentuou nos meses subsequentes. A partis de julho de 1971 esse aumento assumiu características de uma epidemia, em evolução até o presente momento, que se verificou posteriormente ser causada pelo meningococo sorogrupo C. Em abril de 1974 observou-se o aparecí mento de um número crescente de casos determinados pelo meningoco co sorogrupo $A$, caracterizando a presença de uma nova epidemia que se superpunha è primeira. No períado de janeira de 1971 a junho de 1974 foram notificadas e confirmados 4.431 casos.

O objetivo deste trabalho é descrever e analisar alguns as pectos epidemiológicos mais relevantes dessas epidemias no Municí pio de São Paulo até junho de 1974, como uma contribuição nossa às autoridades sanitárias que estão programando e executando medidas para a contrale das mesmas.

Tendo em vista essa finalidade consideramos justifić́vel, rea lizar uma revisão bibliagráfica das principais publicações sobre vacinação antimeningocácica. 0 interesse atual que esse tema re presenta para os sanitaristas é inegável, uma vez que a vacinação parece ser a medida profilática mais eficaz contra a moléstia, a lado de diagnástico precoce e adequado atendimento médico-hospitalas dos casos. 
São recentes a descoberta e a utilização das vacinas polissa caridas grupo A e grupo C. Houve porisso, pouca oportunidade de se verificar sua eficécia durante a evolução de grandes epidemias em áreas abertas, como é a caso atual de São Paulo.

Ds outros munictpios da área da Ğrande São Paulo, também fọ ram atingidos pelas epidemias de meningite meníngocócica.

Um estudo em toda área da Grande São Paulo não foi possível ser realizado pela dificuldade na obtenção de elguns dedos necessá ríg. 
III - REVISÃD BIBLIOGRÁF ICA SOQRE VACINACR̃O ANT IMENINGOCÓCICA

A partir de 1915 inúmeras tentativas foram realizadas no sentido de obtenção de uma vacina imunizante contra a moléstia me ningocócica. As experiëncias de Chalmers e D'Farrel (1915) no $\mathrm{S}_{\underline{H}}$ dão, Davis (1930) no Sudão, Riding e Carkell (1931) no Sudão e Neu jean (1934) no Congo Belga, apresentaram resultados nulos ou incon clusivas (47). No períoda de 1935 a 1940, diversas vacinas france 88s, preparadas pelos Institutos Pasteur de Paris e Dakar com ger mens martos, foram usadas em ensaios controlados na Africa (47) , com resultados mais significativos.

A que apresentou melhores resultados fai a vacinação raali zada em 1936, com muito sucesso, na cidade de Fort-Archambault, no Tchad, país africano do chamado "cinturão meningítico"(*). A vaci na, contendo 5 milhões de germes mortos pela aquecimento a 600 C durante 30 minutas, fai utilizada em 5.000 pessoas (dois terças da população local). Nenhum caso de meningite meningocócica acorreu nos vacinados e nos casos não vacinados ocorreram 23 casos.

Em 1937 foram realizados em diversos países africanos 57.228 vacinaçães. A morbidade pela moléstia fai de 2 por 1.000 habitantes nos vacinados e de 20 a 40 por 1.000 habitantes nos não vacinadas. Em 1939, entre os 51.005 vacinados não hauve nantum ca

(*) 0 cinturão meningítico da África é representado por uma faixa territorial de cerca de 10 milhões de quilometros quadrados, estendendo-se do Oceano Atlantico ao Mar Vermelho, limitada a norte pela deserto e ao sul pela floresta equatorial. Nes sa regijão, onde vivem 35 milhões de pessoas, a meningite me ningocócica ocorre usualmente sob a forma de ondas epidemicas violentas que, começanda no lado leste se propagam para o aes te. 
so. Durante a períada da guerra, de 1940-1945, a vacinaçãa fai mui to reduzida e, quando reiniciada em 1946, não evidenciou as mesmos resultados. O seu insucesso foi atribuido ao fato da cepa de me ningocaco local nãofigurar entre as cepas utilizadas na fabrica çãa da vacina.

Lapeyssonnie (47), em 1963, comentando essas experiências de vacinação na Áfica, concluiu: "A experiência mostrou que, sob certas condições que nos escapam, a vacinação antimeningĺtica tem dado resultados brilhantes na profilaxia da meningite meningocáci ca; um dos primeiros objetivos da pesquisa, se se deseja repensar sobre o problema da vacinação, será determinar quais são as fre ções antigênicas do meningocaco que são imunizantes, isolá-las, de terminar sua natureza química e sobretudo reencontrá-las facilmen te nas diversas cepas".

Esses estudos foram abandonados durante vinte anos em ra zão da descoberta em 1938. da sulfadiazina, que se revelou muito eficaz no tratamento profilático da moléstia. A posterior alarman te sulfaresistência do meningococo (5) estimulou novas, pesquisas sobre vacinação antimeningocócica. Um Centro Internacional de Re ferência para a estuda dos meningococos foi criada em Marselha, dirigido inicialmente pelo Dr. Lapeyssonnie. Os trabalhos para preparação de vacinas foram reiniciados por três equipes:

a) Equipe canadense de Greenberg e colaboradores

b) Equipe do Instituto Mérieux (França)

c) Equipe americana de Gotschlich e colaboradores, do Instituto Rockfeller, e Artenstein e colaboradares, do walter Reed Army Institute of Research. 
Embora as vacinas canadenses e francasas, que vtilizavam os germes inteiros mortos, mostrassem uma reação sorológica sẹ tảsfatória, os resultadas clínicos faram inconclusivas (67)。

Em 1969 a equipe americana publicou os resultados de seus estudos sobre a imunidade humana an meningococo $(30)(31)(35)(36)(37)$ incluindo os testes realizados em seis valuntários humanos com po lissacarides dos meningococos $A$ e C, de alto pesa malecular, abti dos por precipitação de culturas do meningocaco pela adição nas mesmes de um detergente cationico - Cetavlon (35).

0 alto peso molecular do polissacaride parece ter sido res ponsável pelo aumento do seu poder imunogênico, de forma a determi nar nesses voluntáriog uma elevada produção de imunoglobulinas IgM, IgG e IgA. Ds soros tornaram-se altamente bactericidas para o me ningococo A e $C$ após um prazo de duas semanas, e essa ação mantevese inalterada por 5 meses.

Não se observou toxicidade significativa em animais de labo ratúrio ou reações desagradáveis nos voluntários humanos.PosterioI mente, os mesmos autores realizaram uma pesquisa em tres campanties de recrutas militares, com a finalidade de observar a ação da vací na polissacaride tipo C na diminuição do número de portadores (37).

Após 6 semanas de observação as porcentagens de portadores de meningococo $C$ no grupo vacinado da 1a., 2a. e 3a. companhias eram, respectivamente, de $4,6 \%, 24 \%$ e $31 \%$ e no grupo não vacinado de $38 \%, 42 \%$ e $69 \%$.

A partir desses trabalhos fai realizada uma série de en saios de campo com vacinação pelos polissacarides meningocácicos grupo $A$ e $C$. 
Artenstein e colaboradores (2)(3)(29) levaram a efeito pes quisas com a polissacaride meningoć́cica grupo C em recrutas mili tares nos Estados Unidos, com a propósita de determinar a dose óti ma de vacina (3); a melhor via de administração (3), a presença e intensidade de reações locais $(2)(3)(29)$, a necessidade de revaci naçäa (3) e o efeito protetor da vacina contra a moléstia (2)(29). Concluiram pelo uso, em adultas, de 50 mag da preparaçãa, injetada por via sub-cutánea, em uma sá vez (3)。 Dbservaram reaçãa 1ocal caracterizada por eritema de média intensidade, que se iniciou 브 pós 4 a 6 horag, atingiu o máxima em 24 horas e desapareceu dentro de 48 horas $(2)(3)(29)$. Não foi notada qualquer reação geral (2) (3)(29).

Houve elevação significativa do título de anticorpos antimeningacócicos C em 95,3\% dos vacinados após 2 semanas da vacine ção (3)。A revacinação de 13 recrutas após 3 a 4 semanas e de 7 recrutas após 8 meses mostrou ocasionais elevaçães no título de an ticorpos específicos somente nos indivíduos que não haviam apresen tado resposta após a vacinação priméria. Só um dos revacinados, que apresentava elevado título de anticorpos antimeningocócicos $C$, desenvolveu uma acentuada reaçãa local (3)。

Em relação à eficácia da vacina, os autores observaram, em uma primeira experiência (2), uma redução de $87 \%$ dos casos de me ningite meningocócica tipo C no grupo vacinado (13.763 recrutas) com a palissacaride C. Foram observados no total 68.072 recru tas militares durante 8 semanas. Entre os vacinados ocorreram 1 
caso de meningite meningocócica tipo C e 4 casos de meningite me ningocócica tipo B; nas nãa vacinados ocorreram 38 casas de menin gite meningocácica tipo C e 3 casas de tipo $B$, indicando uma gran de especificidade da vacina. a número de portadores de meningoco co C entre as vacinados foi sensivelemente menor durante as 8 seme naв de observação.

Uma segunda experiência (29), realizada com 14.482 milita res vacinados, observados durante 8 semanas ao lado de 60.772 não vacinados, mostrou uma redução de $87 \%$ dos casos de moléstia no grي po vacinado.

Artenstein e colaboradores realizaram também estudos com 4 lotes de polissacarides meningocócicos grupo $A$, injetando-os em 458 militares voluntários (6); as vacinas magtraram-se não tóxicas e altamente imunogênicas, independentemente da via de administre ção (via sub-cutânea com seringa e agulha ou com aparelho jato-in jetor). A dose ótima pareceu ser de $50 \mathrm{mcg}$.

Artenstein (7), consideranda a importância prática da de terminação das condições de estocagem das vacinas polissacarides $A$ e C, efetuou pesquisas para avaliar a estabilidade dessas vacinas em diversas condições, tomando como critério de julgamento sua ca pacidade em provocar uma resposta imunitária em voluntários humaros.

Após liofilização, as vacinas do grupo C mantidas a 49 C conservaram seu poder imunogênico durante 14 meses. A atividade das vacinas liofilizadas do grupo A nãa foi alterada por uma esto 
cagem de 26 meses a -200 C e de 18 meses a 40 C. Seu poder imuna gênica ficou intata após 12 dias em temperatura ambiente e após 3 Hias a 350 C. Após reidrataçãa, as vacinas do grupo C ficaram ati vas durante 3 semanas a 49 C e durente 9 meses a -200 C, enquanto que as do grupo A conservaram seu poder imunogēnico durante 18 dias a -200 C.

Artenstein (B), usando os testes de hemoaglutinação indirẹ ra e imunofiuorescência, mediu os anticorpos no soro, induzidas pe la injeçãa de vacinas polissacarides A e C em 12 valuntários, abser vando que a resposta desses anticarpos se manteve por períodos que excediam 14 meses.

Artenstein e colaboradores também realizaram pesquisas no sentido de comparar a sensibilidade e especificidade dos métodas 느 sados para medir os anticarpos especificos em doentes com a molés tia meningocácica e em voluntários vacinados com os polissacarides C e A。 Ds autores concluiram pela maior sensibilidade dos testes de hemoaglutinação indireta (4), imunofluorescência (4), aglutina ção de partículas de latex sensibilizadas (66) e radioimunoensaio (15).

Foram realizadas várias experiēncias de campo nos países africanos do Senegal, Alto Volta e Mali com vacinas meningocócicas do grupo A, produzidas pelo Instituto Mérieux。 Foram vacinados pm via sub-cutānea e intradérmica adultos e crianças a partir de 6 me ses de idade, observando-se uma elevação na concentração de antị corpos específicos no soro, maior nos imunizados com vacinas de 
maior peso molecular.

Sanborn e colaboradores (59), sob as auspícios da Drganiza Ção Mundial de Saúde, em 1971, realizaram um estuda duplo-cego de vacinação em duas localidades da Nigéria, em 65.972 crianças de 5 a 15 anus, rom a toxóide tetânico e a vacina meningocócica tipo $A$. Não se observou diferença significativa de incidência da meningite meningocócica entre as dois grupos vacinados, assim como qualquer efeito sabre a taxa de portadores. A vacina meningocócica, no en tanto, provocou a produçäa de anticorpos específicos。 Fatores cㅡ ma a exposição da vacina a altas temperaturas e época em que foi realizada a vacinação foram discutidos visanda explicar a insuces sa.

Wahdan e colaboradores em 1971-1972 (69). obtiveram no Egí to. resultados muito diferentes. Foram vacinadas com a toxáide te tânico ou a vacina meningocócica $A, 124.349$ crianças de 6 a 15 a nos de idade, divididas em 2 grupos. Dbservou-se diferença signi ficativa na incidência de meningite meningocócica nos 2 grupos va cinados, assim como entre a grupo vacinado com a polissacaride $A$ e - resta da população da mesma faixa etária (8 casos acorreram nos vacinados com a toxíide tetänico, nenhum caso entre as vacinados com a palissacaride A, 151 casos nas 1.403 .508 crianças não vacina das). Ds autores atribuem a sucesso desse programa de vacinaçãa a tres fatores: a usa de pistolas injetoras, a adequada estocagem e transporte* de vacina e os bem arganizados serviços de saúde. 


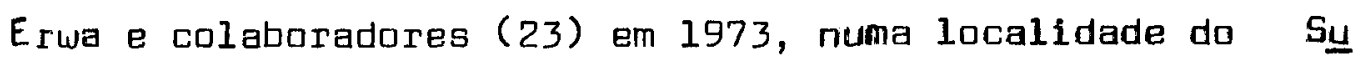
dẽo, vacinarłm em uma população de 161.000 pessuas, 10.891 pessoas com a vacina polissacaride A e 10.749 pessoas com a anatoxina tetạ 7ica. Nas 16 semanas seguintes acorreram 871 casos de meningitere ríngocócica em toda a populaçãa, 10 casos entre as vacinadas com o toxaide tetänica e nenhum caso entre de que receberam a vacina an timeningocócica grupa $A$, indicanda um efeito protetar desea vacina.

Considerando-se a alta incidëncia da moléstia abaixa dos 10 anos de idade e sua elevada letalidade nesse grupo (60\% dos ábi tos por meningite meningocócica nos Estados Unidos ocorreram em crianças abaixo de 10 anos) (32), inúmeras estudos foram realiza dos com as vacinas polissacarides nesse grupo etárío

Riley (57) relata uma pesquisa de Lepow e colaboradores(1973), nos Estados Unidos. Foram vacinadas 60 crianças de 1 a 9 anos de idade com 25 mcg ou 50 mcg de polissacarides meningocácicos. Trinta crianças receberam a antígeno grupo A e trinta o antígeno grupo $C$. Dentro de 2 semanas da vacinação, em 50 crianças houve produção de anticarpos específicos a níveis comparáveis àqueles produzidos em adultos vacinados, independentemente da dose de 25 mcg ou 50 mcg in jetada.

Ds mesmos pesquisadores estenderam seus estudas a latentes abaixa de 1 ano de idade (32)。Quarenta e oita crianças de 7 me ses a 9 anos e meio foram injetadas subcutaneamente com 25 mcg e 50 meg de polissacaride $A$ e $C$. Ds resultados foram semelhantes a 
wo estudo anterior, tendo sido encontrados anticorpos específicos no sora das crianças 10 a 15 meses após as imunizações. Em nenhum dos trabalhas se constataram reaçães tóxicas.

Manto e colaboradores (1973), nos Estados Unidos (52) ing cularam 102 crianças de 2 a 6 anos de idade com quantidadea variá veis de vacina polissacaride C. Doses de 5 mag, 25 mcg e 50 mag mostraram-se menos satisfatórias na produção anticorpos do que dㅁ ses de $100 \mathrm{mcg}$ ou $200 \mathrm{mcg}$. A resposta dos anticorpos fai direta mente proporcional à idade, e sempre menor que a de 24 adultos ing culados com $50 \mathrm{mcg}$ de polissacaride $C$. Dito meses após a primeira inoculação 49 crianças receberam simultaneamente $50 \mathrm{mcg}$ de polisøe caride A e $50 \mathrm{mcg}$ de polissacaride C. Todas responderam satisfato riamente à vacina $A$, independentemente da dose da primeira vacina ção. Em relação à vacina $[$ a elevação de anticorpos específicos foi maior nos que haviam recebido mais altas doses na primeira ing culação.

Em 1972 a Secretaria de Saúde do Estado de São Paulo, em colaboração com técnicos da Drganização Mundial de Saúde, realizou em São Paula um estudo duplo-cego de vacinaçãa em 134.017 crianças de 6 a 36 meses de idade. Foram vacinadas 66.817 crianças com 50 meg de vacina polissacaride C e 67.200 crianças com a toxáide dif térico-tetânico. A elevação de anticarpos específicos observada en dois grupos de crianças vacinadas no Hospital do Servidor Público de 5ão Paulo e Faculdade de Medicina de Ribeirão Preto ocorreu de forma mais evidente nas crianças de maior idade (*)

* Informação verbal fornecida a pedido pelo Dr. Augusta Taunay Diretar do Instituto Adolfo Lutz e Coordenador do Programe de vacineção Antimeningítica realizado no Município de Sảo Paula, em dezembro de 1972. 
Os resultadas da vacinaçãa em termos de proteçãa contra a moléstia mostraram que não houve, estatisticamente, proteção no grupo de 6 a 23 meses, mas houve proteção no grupo de 24 a 36 me ses (65). Assim, entre janeira de 1973 e abril de 1974, ocorreram no grupo de 6 a 23 meses 16 casos de meningite meningocócica tipo E ne grupo vacinado com a palissacaride $C$ e 18 casos no vacinada com a taxáide tetânico-diftérica.

No grupo de 24 a 36 meses de idade ocorferam 4 casas nos va cinados com a palissacaride C e 15 casos nos vacinados com a taxái de tetânica-diftérico.

E provável que uma dose maior da vacina antimeningocócica C ou a aplicaçãa de uma dose de reforço aumentasse a proteção à mo léstia no grupo etário de 6 a 23 meses.

Mais recentemente, Goldschneider e colaboradares (1973)(33) realizaram estudos em 92 crianças de 10 semanas a 21 meses de ide de, injetadas com doses de 12,5 mcg a $100 \mathrm{mcg}$ de polissacaride C e 25 mcg e 50 mcg de polissacaride A. Com 7 a 18 meses, algumas cri anças receberam imunização de reforça. A concentração de anticon pos específicos foi medida após 4 semanas de cada imunização. Ds resultadas revelaram: a) ausência de reações gerafue e locais adver sas; b) sempre houve produção de anticorpos específicos, mas não houve relação clara entre a dose de antígeno administrada e a pro duçãa de anticorpos; c) não houve diferença significativa entre as respastas de anticarpos das crianças de 3 a 7 meses após 4 sema nas da imunizaçãa primária. Essas crianças apresentaram significa 
tiva elevação da concentraçãa de anticorpos aos 7 e 18 meses de idade, após vacinaçãa secundária, quando comparadas a crianças não imunizadas; d) as crianças de 18 meses produziram concentraçães de anticorpos significativamente maiores que as de 3 a 7 meses a pós imunização primária com polissacaride $A$ e C. A resposta à va cinação de refarço do antígeno grupo C não diferiu da induzida pe la vacinação primária, mas houve diferença significativa na respog ta de anticorpos após a vacinação primária e secundária com a antî geno grupo $A(4,69 u g / m l$ para $9.10 u g / m l)$; e) a administraçãa simul tânea de vacinas grupo A e grupo C em seringas separadas não alte rou a resposta dos anticorpos aos antígenos.

A capacidade das crianças abaixo de 2 anos de responder aos antígenos polissacarides meningocócicos parece ser dependente da idade, seja pela crescente maturidade da sistema imunológica, seja pela crescente possibilidade de imunização natural com o antígeno completo.

Com a finalidade de verificar a efeita da vacina quanda in troduzida no organismo pelo mesmo local da infecção natural, Wenzel a colaboradores (1973) (70) administraram a vacina polissacaride C por via intranasal em dases de $50 \mathrm{mg}$ (Grupo I e II) e $200 \mathrm{mg}$ (Grupo III), em 3 grupos de 20 marinheiros que foram abservados duran te 5.semanas. Após 2 semanas acorreu significativa elevaçãa de an ticorpos especificos no soro de 45\% (Grupo I), 29\% (Grupo II) e 70\% (Grupo III) dos homeng vacinados. Não se produziu elevação expres siva dos anticorpos nas secreções nasais. A resposta de anticor pos no soro, determinada pela infecção natural, foi 2 a 3 vezes 
maior que a conferide por $200 \mathrm{mg}$ da vacina administrada por via in tranasal.

Em relação à vacina palissacaride $\theta$, Artenstein e colabora dores (10) a prepararam e testaram em militares. Porém verifica ram passuir baixa pader imunogênica.

Até o momento, tem-se usado vacinas polissacarides. grupo especificas. E possivel que a imunidade contra todos os grupos de meningococos possa ser adquirida com a uso de polissacarides de ra ças não patogênicas que contenham os mesmos antígenos ou antígenos similareg grupo específicos (57).

Jennings e colaboradores (1972) (42) obtiveram de um extra to de células de meningococos soro grupo $Y$ com uma solução aquosa de cloreto de cálcio, um poderoso antígeno que apresentou, pela técnica de imunodifusão, reação de precipitação com os antisoros dos sorogrupos A, B, C, D e Z. Esse antígeno revelou-se capaz de determinar boa imunidade em ratos para os sorogrupos hamálogos e heterólogos do meningococo. Ds autores supõem que esse antígeno é de natureza protéica e propãem o seu emprego em voluntários huma nos para uma avaliação.

O emprego de uma vacina polivalente tem sua justificativa: diversos autores abservaram a acorrenncia de casos de meningite em populações vacinadas, determinados por grupos de meningocodos di versos dos das vacinas polissacarides grupos especificos com que tinham sido imunizadas. Artenstein e colaboradores ( 3 ) observaram 
Uima incidència da meningite meningocócica grupa $\theta$ maior entre re

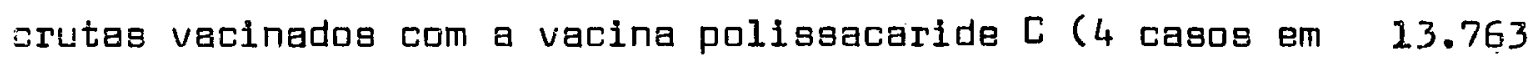
Fessces - 0,291 por mil) do que entre os não vacinados (3 cagos em 54.309 pessoas - 0,55 por mil). Dbservarem também que a reduçãa ma taxa de portedorae de meningococo grupo C entre og vacinadoa fai acompenhada de um aumento na taxa de portadores de outros eorogru pas (37). Artenstein e colaboradores (3) e Finland (25) argumen tam que o uso em larga escala de uma vacina monovalente pode resul tar no aparecimento de outros soragrupos camo causadores da molége tia e preconizam a uso de uma vacina que contenha as antígenos das grupos A, B e C, uma vez que os mesmas determinam 90\% dos casos de moléstia: meningocócica. No entanto, lembram que os efeitas do largo uso dessa vecina polivalente não podem ser previstos, uma vez que existem outras sorogrupos X, Y, Z, $29 E$ e 135, atualmente causadores pouco frequentes da moléstia.

$\underline{z==\pi=0}$

A revisãa dos trabalhos sobre vacinação antimeningocócica mogtra reaultados multo satisfatórios das vacinas poliseacaridea meningocócicas A e C nos individuos acima dos 2 anos de idade: E旦 aag vacinas são grupo específicas. Pauco se conhece sobre seu efeito quando utilizadas durante grandes epidemias da moléatia em extenses áreas geggráficas. O seu emprego atual na região de Gran de São Paulo é uma medida oportuna, sendo de extremo valor a ave l1açẽo de sua eficácia nẽo só em termos da diminuição do número de doentes, camo do número de portadores. 
IV - SITUACĂD DA MENINGITE MENINGOCÓCICA ND BRASIL E ND MUNICIPID DE SÃO PAULD

Da dados de morbidade par meningite meningocócica no Bragil, de 1968 a 1972, disponíveis na Secção de Vigilância Epldemiológica da Divisão Nacional de Epidemialogia (D.N.E.E.S.), estão englaba dos na denominação de meningites em geral (16). Contuda, com a eclaaão do surta de meningite meningocácica em São Paulo em julho de 1971 e, a seguir, em outras unidades da Federação, a intereses pela 1dentificação desse tipo de meningite aumentou, estimulado pe 1o Ministério da Saúde, visando inclusive a sua vigilância e con trole.

A partir de 1972 o D.N.E.E.5. registrou maior concentração de casos de meningite em gerel, cam elevado número de casas de me ningite meningacócica em 9 Estadas, excluindo São Paula (16):

Acre: em 1973 - 369 casos de meningites, dos quais 59 con firmados como meningite meningocócica; desses $56 \mathrm{com} 13$ ó tos ocorteram em Rio Branco.

Ceará: em 1972, 507 çasos de meningite em geral, sem espe cificaçãa de meningocócica.

Alaggag: em 1973, 161 casos de meningites - 60 considera dos como meningač́cica, acgrridas em 15 municípios, com maior concentração em Maceio ( 29 casas) e Santana do Mundaú (10 casos).

Goís: em 1972, 312 casos, 72 devidos a meningite meningo cacica. Em 1973, 541 casos de meningites em geral, dos quais 265 de meningite meningocócica.

Espírito Santo: em 1973, 379 casos de meningites, das quais $\overline{146}$ de meningite meningocócica (20 casos em Colatina entre março e abril)

Guanabara: em 1972, 48 casos de meningițe meningocócica, e em. 1973, 128 casos de meningite meningocácica. 
Minas Gerais: dos 62 casas de meningite meningocócica re gistrados em 1973, 46 casos ocorreram em Ipatinga, grande parte provavelmente de natureza meningocócica (sem compro vação laboratorial). Em 1974, até julho, 104 de meningite meningocácica, dos quais 78 casas em Ipatinga.

Paraná: em 1973, a partir de julho, um aumento acentuado da meningite, atingindo um total de 1.935 casos anuais de meningite em geral, sendo 350 referidas camo meningacócicas (infreqbente a confirmação laboratorial)。

Rio Grande do Sul: em 1973, 1.479 casos de meningites em geral, cam 647 confirmados como meningite meningacóclca.

Em 1974 prosseguem altos percentuais de meningite meningocó cica nos estadas do Ceará, Paraná, Gaiás, e Rí Grande do Sul.

Em relação a outras meningites, a situação da meningite me ningocócica no Municípị de são Paula, foi já ralatada em 1932 por Carvalho Lima (50) que, em um levantamento feito de 1928 a 1931 , encontrou 84 casas $(36,5 \%)$ de meningite meningocócica entre os 230 casos de meningites bacterianas diagnosticadas laboratorialmente.

Schmid e Galvão (62) referem, no períada de 1955 a 1959 nо Município de 5ão Paula, uma porcentagem de 33,4\% de meningites me ningocócicas em relação às meningites de etiologia identificada, porcentagem essa que se reduz a $22,6 \%$ quando consideradas na soma também as meningites indeterminadas。

Bastos e colaboradores, mais recentemente, em um levantamen to feito no Hospital Emílio Ribas (13) no períado de janeira de 1958 a julho de 1974 encontraram a seguinte proporção de casas: 


\begin{tabular}{|c|c|c|c|}
\hline ANOS & $\begin{array}{c}\text { MENINGITES } \\
\text { EM GERAL }\end{array}$ & $\begin{array}{c}\text { MENINGITES } \\
\text { MENINGOCÓCICA }\end{array}$ & PURCENTAGEM \\
\hline $1958 / 1970$ & 9.895 & 1.535 & 15,5 \\
1971 & 1.771 & 627 & 35,4 \\
1972 & 3.401 & 1.579 & 46,4 \\
1973 & 5.195 & 2.823 & 54,3 \\
$1974 *$ & 6.725 & 3.805 & 56,6 \\
\hline
\end{tabular}

(*) Dados até o mes de fulho, pasef́lvis de altarações.

Esea porcentagem deve ger ma1or, uma vez que entre es menin g1tes de etiologia indetemineda, devem egtar 1nd́luldos os casos de meningite meningocócica que não foram ident1ficadog por mativas dî versos, tals como:

- emprego de antibióticos ou quimiaterápicos antes do ingresso no hospital;

- contaminação do liquido cefalorraquidiano par ocagiãa de sua co Ihe1 ta;

- Liae da meningococo durante a transparte do materlal para o la boratório.

De primelros casos de meningite meningocócica diagnosticade no Múnicf́pio de São Paula, segundo Junqueira (43), datam de 15 de fevereiro de 1906; tratava-se de quatro estrangeiros chegados pou co antes ì Imigração. Degde esea data até 31 de dezembro de 1913 foram Internados no Hospital do Isolamento 53 doenteg. Acredita Junqueira que não fossem os únicos casos nesegs 7 anos, embora moléstia se apresentasse em caráter esporádico.

Assumpçãa (11) relata 478 casos no perf́lado de 1921-28, com - coeficiente máximo anual, em 1922, de 15,2 casos por 100.000 ha 
bitantes, e uma letalidade máxima de 60,5\% em 1926.

De 1935 até 1944 os regiatros da Secção de Epidemiologia e Profilaxia Geraia do Departamento de Saúde da Secretaria de Saúde Pública e Assiatência Social de Sẽa Paula, (SEPG), relatam coefí cientes anuais variáveis de 2 a 4 casos por cem mil habitantes. Em 1945 tem início uma epidemia da meléstia, que perdura até 1951, ten do os coeficientes de morbidade atingida seu ponto máximo em 1947: 25 casos por 100.000 habitantes (62).

Em 1951 os valores eram de 4,8 casos por 100.000 habitantes, continuando a abaixar até 1,7 casas par 100.000 habitantes em 1958 (62). No período de 1959 a 1970 situava-se em tarno de 2 casos par 100.000 habitantes, mantendo essa média até abril de 1971 quando se incia uma nova epidemia.

A variação secular da meningite meningacócica no Município de São Paula eatá expressa no gráfica ne 1. (perílodo de 1930 a 1973). 


$$
\Delta
$$


$V$ - MATERIAL E METODOS

A área estudada, a município de 5ão Paulo, ocupa uma exten são de $1.509 \mathrm{Km}^{2}$ (60). Situa-se na parte central da região metro palitana da Grande 5ão Paulo, que é composta de 37 municlpias e constitui uma das regiões administrativas do Estado de São Paula. [Mapa anexa]

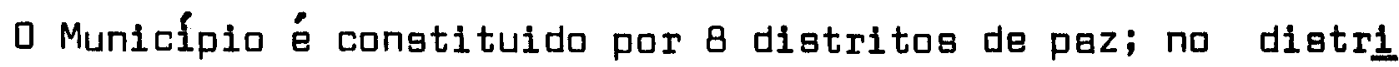
to de São Paulo, constituida por 48 sub-distritọs de paz, reside 88\% da populaçãa do Município (61). Essea distritas e sub-distr 1 tos de paz foram agrupados adminigtrativamente pela Secretaria de Saúde, em 4 Divisões de Saúde, abrangendo 13 Distritos Sanitários:

R1-1 - Divisão São Paulo - Centro:

Distritos Sanitários de Santa Cecfila, Vila Mariana e Be lemzinho.

R1-2 - Divisão São Paulo - Leste:

Diatritas Sanitários de Vila Maria, Penha de França a São Miguel Pauliata.

R1-3 - Divisão São Pauḷo - Sudeste:

Distritas Sanitários de Jabaquara e Vila Prudente.

R1-4 - Divisão 5ãa Paulo - Narte-Deste:

Distritos Sanitários de Butantã, Santo Amaro, Lapa, Nossa Senhora do o a Tucuruvi.

As três últimas Divisões de Saúde abrangem também as outras 36 municf́pios da regiẽa da Grande 5ão Paulo: [Vide mapa anexa]

o clima do Município é tropical temperada de altitude. A tem peratura média anual esté em tarno de 250 C. A média mensal atinge agus valores mínimos, abalxa de 230 C, nos mesea de maía a agog 
to, sendo julho a mês de mais baixa temperatura, quando também a amplitude entre a máxima e a mínima atinge os maiores índices: $12,300[(60)$.

A população do Município é de 5.931.595 de habitantea, de acordo com o censo de 1970 (61). Segunda dados de uma pesquisa do miciliar da Secretaria de Economia e Planejamenta da Estada de Sãa Paula, colhidas em 1971, 46,5\% das famflias do Municf́pio têm renda familiar mensal até 2 salários mínimos; $38,0 \%$ renda familiar entra 2 a 6 salários mínimos; e 15,5\%, renda familiar acima de seis salá rios mínimas (60).

Para este estudo epidemiológico, a casa de meningite meningo cócica se refere an caso notificado ao Serviço de Epidemiologia u de Divisãa Regional de Saúde da Grande 5ão Paulo (R1-E da DRS-1) como meningite meningocócica, meningite por diplococo Gram negati vo ou meningococemia.

Para levar a efeito este estuda, tivemos que manusear peg soelmente as fichas epidemiológicas, pois na tabulação de dados pe 1o Serviço de Epidemiologia intervieram divereos fatores que prejü dicaram a uniformidade das suas infarmações:

1) - até julho de 1973 as meningites por diplococos Gram negativos não foram incluidas entre as meningites meningocacicas;

2) - entre 1967 a 1971 inclusive, as meningococemias não foram in cluldas entre as meningites meningocócicas;

3) - até 1961, eatãa incluidas as dados da Municíplo de Daasca, que pertenceu ao Município de São Paula até esse ano. 


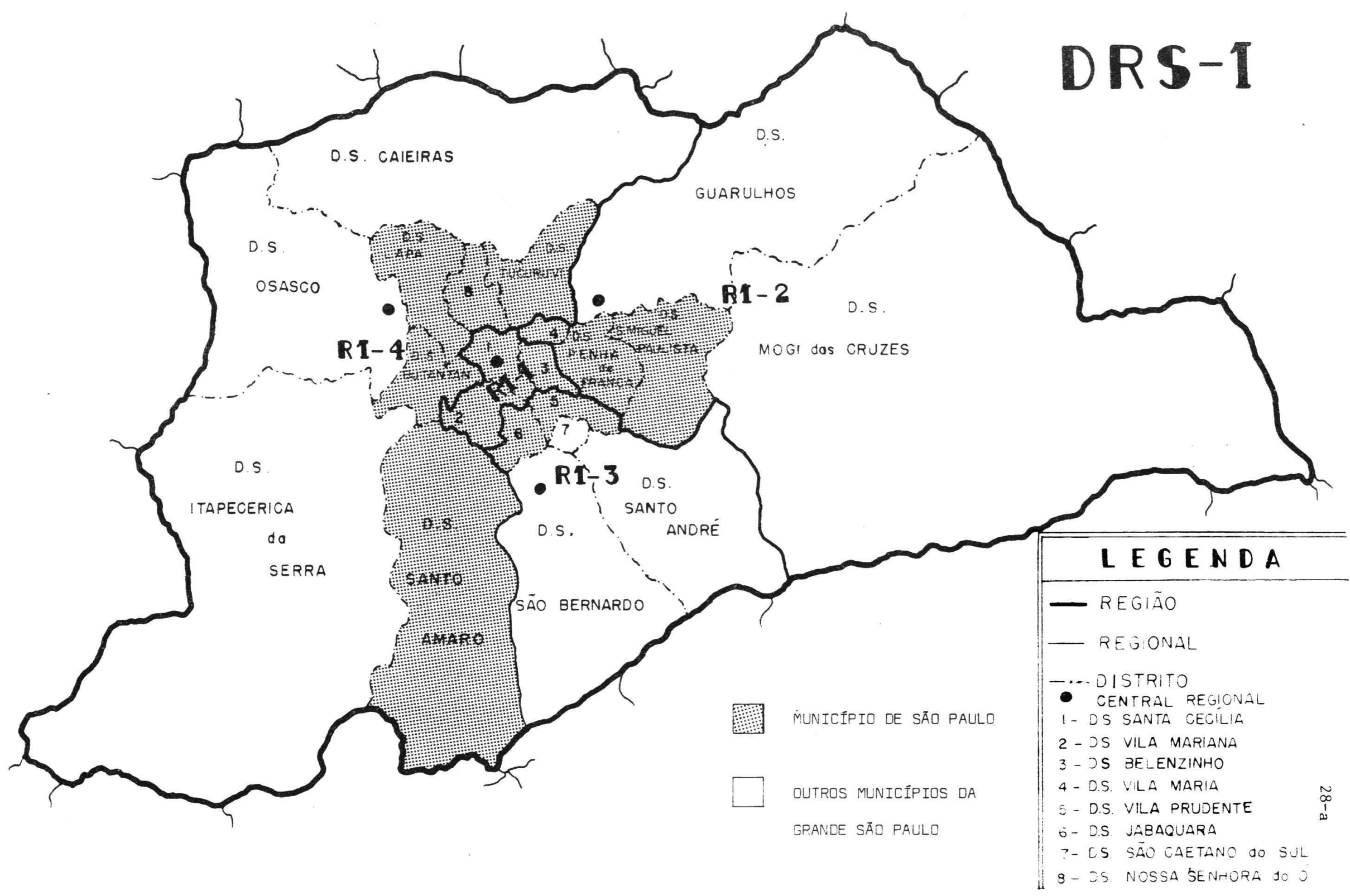


Serão estudados os casos residentes no município de 5ão Paㅡ 10, internados nos haspitais de 1 de janeiro de 1968 a 30 de ju nho de 1974 (*).

Até julho de 1974, cerce de noventa por cento dos doentes fa ram Internados no Hospital Emílio Ribas, hospital estatal de molége ties infecciosas. 0 diagnóstico laboratorial das meningites menin gocácicas e por diplacocos Gram-negativos desses doentes foi reali zado no Instituto Adolfo Lutz. Ds casos de meningococemia foram diagnosticados clinicamente, geralmente sem hemocultura.

Pesquisamas durante o ano de 1973 os casos de meningite me ni̊ngocócica notificados pelos laboratórios particularea a Serviço de Epidemiologia da Divisãa Regional de Saúde da Grande 5ãa Paulo (DRS-1). Foram 48 casos que não foram internądos no Haspital Em 110 Ribas e Haspital do Servidor Pública. No mesma ano, esses hospitals notificaram 1.643 casos de meningite meningocócica no Mㄴ niclplo de 5ão Paula.

Marais e calaboradares (53), em um levantamento feito em ju lho de 1972 no Laboratório Adolfo Lutz, laboratório do Hospital do Servidor Público e laboratórios de análises particulares do Municí pio de São Paulo observaram que, dos 260 exames de líquida cefalo requidiano positivos para meningococos, só 26 (10\%) nãa pracediam do Hospital Emílio Ribas.

(*) 1968,1969 e 1970 serãa uaadog como per্রíndo pré epidêmico e 1971, 1972, 1973 \& 1974 - períada epidemica. 
0 diagnóstico laboratorial de ratina da meningite meningocó cica realizado pelo Instituta Adolfo Lutz (**) era baseada, até ju Iho de 1974, no exame bacterioscópico direto da líquido cefalora quidiano, que identifica o diplococo Gram negativo, e na cultura do mesmo líquido para a identificaçãa da Neisseria meningitidis. Nos casos em que o primeira exame fosse positivo a nã̃ houvesse crescimento des culturas, a diagnástico emitido pelo laboratário era de meningite par diplococo Gram negativa.

Para o exame bacterioscópico direto são feitas duas prepara ções, uma corada pelo métada de Gram e outra pelo métada de ZiehlNielsen.

As culturas são realizadas em agar sangue, agar chocolate com base de melo de Muller-Hilton e agar triptocage-8aja e colocadas em estufa a 350 - 360 C. A semeadure imediatamente após a colhe1 ta, eendo a material mantido em estufa até ser transportado do Hoge p1tal Emflia Ribas para o Laboratário Adolfo Lutz fai, adatada a partir de janeiro de 1972, com a finalidade de reduzir a número de culturas negativas. Ag culturas sãa observadas depois de 24 e 48 horas. Hevendo crescimento de colônies, realiza-ge a bacteriosco pia, a teste de axidase e as séries para verificar fermentaçãa de açúcares [dextrose, maltose e sacarose].

A sorotipagem foi realizada a partir de outubra de 1972, cam a日 provas de aglutinaçãa do material das culturas pelos antisoros especificos.

(**) dados fornecidas pela Dr. Gil Vital Pessoa, Chefe da Seç̧ãa de Bacteriologia Médica do Instituto Adolfo Lutz. 
A imunoeletroforese cruzada, imunofluorescência e hemoggluti nação: indireta são realizedas desde 1972 na 5ecção de Imunologia nos doentes de 0 a 4 anos de idade, situadas dentro da faixa eté ria dos que receberam vacinação antimeningocócica tipo C em dezem bro de 1972. (*)

A 1munoeletroforese cruzada passou a ser usada rotineiramente na Secção de Bacteriologia a partir de julho de 1974.

A identificação de Neisseria meningitidie pelo Instituta Adgl fo Lutz fai confirmada pelo Special Pathogens Laboratory, Bureau of Epidemiology, Center far Disease Control (L.D.C.) nos E.U.A. No período de outubro a novembro de 1972 para 68 culturas positi vas de líquor cefaloraquidiano, $8(8,8 \%)$ era sorogrupo 日 e 62 $(91,2 \%)$ era sorogrupo C.

Pesquisada a sensibilidade à sulfadiazina, 95,1\% do tipo C e 33\% do tipo 8 foram resistentes a 1,0mg\% de sulfadiazina (53). Neg sa ocasião não fai encontrado o meningococo tipo $A$, cuja presença se tornou progressivamente crescente a partir de abril de 1974.

Os dadas de obituário registrados no Serviço de Epidemialo gía da Divisão Regional de Saúde da Grande São Paulo nãa parecem exṕressar a totalidade do obituário pela moléstia no Município de São Paulo.

(*) dados colhidas na Secção de Imunologia do Instituto Adalfo Lutz. 
Um levantamento feito por Laurenti (48) sobre as causas bási cas e múltiplas de óbitos hospitalares no distrito de 5ão Paulo, ande reside 88\% da populaçãa do Municípia, no períado de 1/3/1971 a 28/2/1972, mostra através de dados aficiais (atestadas de óbitos), 57 ábitos nos quais a meningite meningacócica e meningacocemia sãa dadas como causas básicas. A investigação individual de todos os óbitos hospitalares feita por Laurenti eleva para 72 esse número, revalando uma deficiência no preenchimento do atestado de ábita.

No mesma período foram notificados an Serviço de Epidemiolna gia do DRS-1, 49 ábitos de residentes no Município de São Paulo causados por meningite meningocócica e mrningococemia.

De acordo com a legislação vigente, as óbitos são registrados nos cartórios do local de ocorrência dos mesmas, e não nos caI tários do local de residência da pessoa falecida. Até 1972 o De partamento de Estatística do Estado de São Paulo registrava os óbi tos sá pelo local de ocorrência. Dessa farma a Município de São Paula, pelas próprias condiçães de uma melhor rede hospitalar, apre sentava invasão de ábitas de outras municípios. Em relação à me ningite meningocócica isso se torna mais evidente, considerando que o Hospital Emílio Ribas atende daentes de autras municípios da Grande São Paulo, além de alguns municípios do interiar da Estada.

Assim, no períada estudada de 1968 a 1973 não faram calcula das os coeficientes de mortalidade, sendo calculada apenas as poI centagens de letalidade dos casos notificados e confirmados an SeI viço de Epidemiologia da DRS-1. 
Não foi feita a tabulação da letalidade por distritos sanitá rios, pois seria necessério um levantamento de todas as fichas epl demiológicas, uma vez que a tabulaçãa nåa é feita na Serviça de Epidemiologia. Esses dados nos parecem de interesae para uma ava liaçãa da relaçãa entre letalidade e morbidade, letalidada e servi ços de assistência médica, letalidade e nfvel sócioeconômico da po pulação. Em um levantamento amostral que realizamos no primeito semestre de 1973 nos distritos sanitários de São Miguel e Santo Amaro, esegs diatritos apresentaram cada um, 118 casos de meningl te meningacácica (coeficientes de morbidade de 15/100.000 habitan tes respectivamente).

A letalidade diferiu aignificativamente: em 5ão Miguel fai de 5,1\% (8 b́b1tos) a em Santo Amaro fol de 11,9\% (14 ób1tog). Eg ses números nẽo permitem uma conclusẽo, pois referem-sв a um perf̣n do de apenas 6 meses de epidemia em 2 distritos sanitários mala atingidos. Serla intersesante completar es8eg dados com um eatuda posterior, embora dado o grande número de fichas a serem manusea das, isso venha a ser trabalho muito demorado.

Os dados populacionais globais e por distritos sanitários fọ ram estimadas pela Secção de Demografia Dinâmica da Divieãa de Eg tatística Demográfica do Departamento de Estatística da Secretaria de Economia e Planejamento de São Paula, segunda a processa que considere, além do seldo vegerativa, a saldo migratário, medida através de coeficientes médios encontrados com base nos últimos censos. 
A população por sexo e grupos etários fol estimada a partir do Censo de 1970, pelo ć́lculo de extrapolação lineer dos coefí clentes respectivos encontrados nesse Censa.

Nãa existem dadas populacianaig nos últimas censos relativas 永 raça日, que permitam celcular as coeficlentes de morbidade regpec tivas.

Na ficha epidemiológica das doentes constam sá alguns ques1 tos (acupação, natureza da habitação) que permitam classificá-los sócioeconomicamente.

Seria interessante verificar no Municipio de São Paulo o rí co de meningite meningocócica para pessoas de diferentes raças e extratos sócioeconômicas.

As abservações de outros autores sobre esse assunto sãa con tradirórias. (26)(46)

A distribuição geográfica dos casos foi feita por diatritos aanitários, critério adatada pela Secçãa de Epidemiologia da Divi 8ão Regional de Saúde da Grande 5ãa Paulo, a partir de 1972. A la calização dos casos por sub-distritos a distritas de paz proporcion naria uma visãa mais precisa de epidemia.

Na tabela 6 e 11 foram apresentados dados referentes à toda área da Grande 5ãa Paulo pals a epidemia por meningococo sorogrupo A, nos primeiros meses de evolução, atingiu mais os municipios pe 
riféricos dessa área. Dessa forma fica mais clara o que se preten de evidenciar nessas tabelas, ou seja, a rápida evoluçãa da epidê mia sorogrupo $A$ e a diferente distribuição etária dos casas no prî meiro mes de epidêmia sorogrupo A ern relação à epidêmia saragrupo ᄃ. 
$V I \quad-$ RESULTADOS

1. Meningite meningocócica e meningite por causa indeterminada. Um bom número de meningites determinadas pelo meningacoco está incluida entre as meningites de causa indetermirada, por nãa identificaçãa da bactéria no axame bacterioscópico ou na cultura.

Há um paraleliamo entre as curvas de incidência mensal da meningite meningocícica e de causa indeterminada, até 1972.

Nos últimos meseg de 1972 a em 1973 a 1974, essas curvas distanciam-se entre si apresentando traçadas diferentes (Tabela no 1 e 2 в Gráfico no 2).

A latalidade das meningites de cerlsa indeterminada é muita alta, chegando, em 1969, a 42\% dar cagog。 Em 1974 diminu1 acentuadamente (Tabela n 3 ). 
TABELA Nọ 1

DISTRIBUI ÇAO MENSAL DA MORBIDADE POR MENINGITE MENINGOCOCICA NO MUNICIPIO DE SÃO PAULO NO PERTODO DE 1968 - 1974.

\begin{tabular}{|c|c|c|c|c|c|c|c|c|c|c|c|c|c|c|}
\hline \multirow[b]{2}{*}{ Mes es } & \multicolumn{2}{|c|}{1968} & \multicolumn{2}{|c|}{1969} & \multicolumn{2}{|c|}{1970} & \multicolumn{2}{|c|}{1971} & \multicolumn{2}{|c|}{1972} & \multicolumn{2}{|c|}{1973} & \multicolumn{2}{|c|}{1974} \\
\hline & Casos & Cof。 & Casos & Coef。 & Casos & Coef. & Casos & Coef. & Casos & Coef. & Casos & Coef. & Casos & Coef. \\
\hline Janeiro & 8 & 0,15 & 3 & 0,05 & 11 & 0,18 & 13 & 0,21 & 49 & 0,75 & 74 & 1,09 & 132 & 1,86 \\
\hline Fevereiro & 8 & 0,15 & 9 & 0,16 & 6 & 0,10 & 7 & 0,11 & 33 & 0,51 & 84 & 1,24 & 89 & 1,25 \\
\hline Março & 8 & 0,15 & 6 & 0,10 & 4 & 0,07 & 6 & 0,10 & 32 & 0,49 & 107 & 1,58 & 111 & 1,57 \\
\hline Abril & 3 & 0,05 & 9 & 0,16 & 7 & 0,12 & 19 & 0,31 & 21 & 0,32 & 127 & 1,87 & 176 & 2,48 \\
\hline Maio & 12 & 0,22 & 8 & 0,14 & 12 & 0,20 & 21 & 0,34 & 69 & 1,06 & 141 & 2,08 & 253 & 3,57 \\
\hline Junho & 7 & 0,13 & 7 & 0,12 & 13 & 0,22 & 23 & 0,37 & 97 & 1,49 & 152 & 2,24 & 444 & 6,26 \\
\hline Jutho & 8 & 0,15 & 10 & 0,18 & 15 & 0,25 & 51 & 0,82 & 176 & 2,71 & 147 & 2,16 & - & - \\
\hline Agos to & 5 & 0,09 & 8 & 0,14 & 17 & 0,29 & 54 & 0,87 & 105 & 1,62 & 186 & 2,74 & - & - \\
\hline Setent ro & 8 & 0,15 & 8 & 0,14 & 8 & 0,13 & 39 & 0,63 & 107 & 1,65 & 190 & 2,80 & - & - \\
\hline Outubro & 4 & 0,07 & 5 & 0,09 & 4 & 0,07 & 61 & 0,98 & 117 & 1,80 & 205 & 3,02 & - & - \\
\hline Novemb ro & 4 & 0,07 & 1 & 0,02 & 12 & 0,20 & 59 & 0,95 & 119 & 1,83 & 194 & 2,86 & - & - \\
\hline De zemb ro & 2 & 0,04 & 14 & 0,25 & 13 & 0,22 & 59 & 0,95 & 90 & 1,38 & 192 & 2,83 & - & - \\
\hline TOTAL & 77 & 1,4 & 88 & 1,5 & 122 & 2,1 & 412 & 6,6 & 1015 & 15,6 & 1799 & 26,5 & 1205 & 17,0 \\
\hline
\end{tabular}

FONTE: Seção de Epidemiologia - Departamento Regional de Saúde da Grande São Paulo Secretaria de Saúde de São Paulo - RT-E DRS-1

Instituto Brasileiro de Geografia e Estatistica - IBEE

(*) Dados atē junho

Coef. $=$ coeficiente por 100.000 habitantes

Departamento de Estatística da Secretaria de Economia e Planejamento de São

Paulo - D.E.S.E.P. 
TABELA NO 2

DISTRIBUIÇAOO MENSAL DA MORB IDADE POR MENINGITE DE CAUSA INDETERMINADA

NO MUNICIPIO DE SAO PAULO, NO PERTODO DE 1968 - 1974

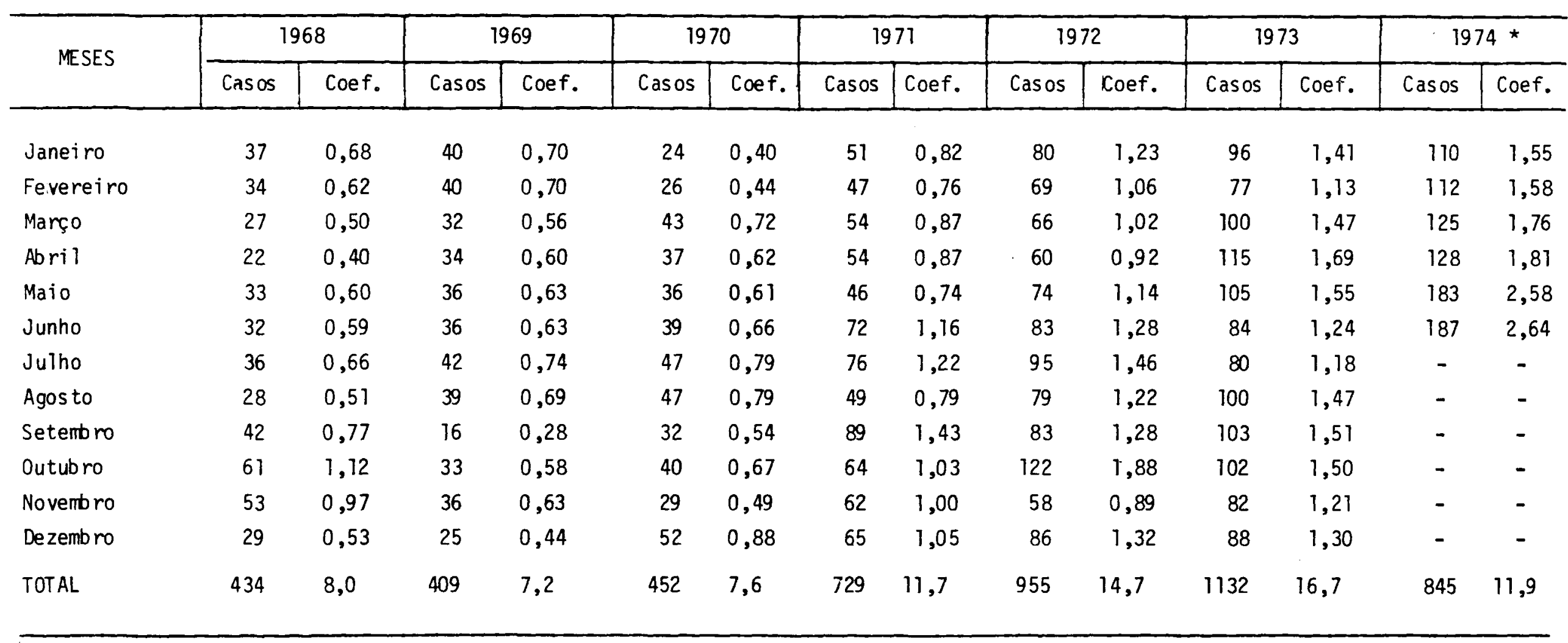

FONTE: Seção de Epidemiologia - Departamento Regional de Saúde da Grande São Paulo - Secretaria de Saūde de São Paulo

Instituto Brasileiro de Geografia e Estatística

Departamento de Estatística da Secretaria de Econamia e Plane jamento de São Paulo.
(*) Dados atē junho

Coef. = Coeficiente por 100.000 habitantes 
DISTRIBUIÇÃO MENSAL DA MORBIDADE POR MENINGITE MENINGOCÓCICA

E POR MENINGITE DE CAUSA INDETERMINADA NO MUNICIPIO DE SÃO PAULO

NO PERIODO DE 1968 a 1974

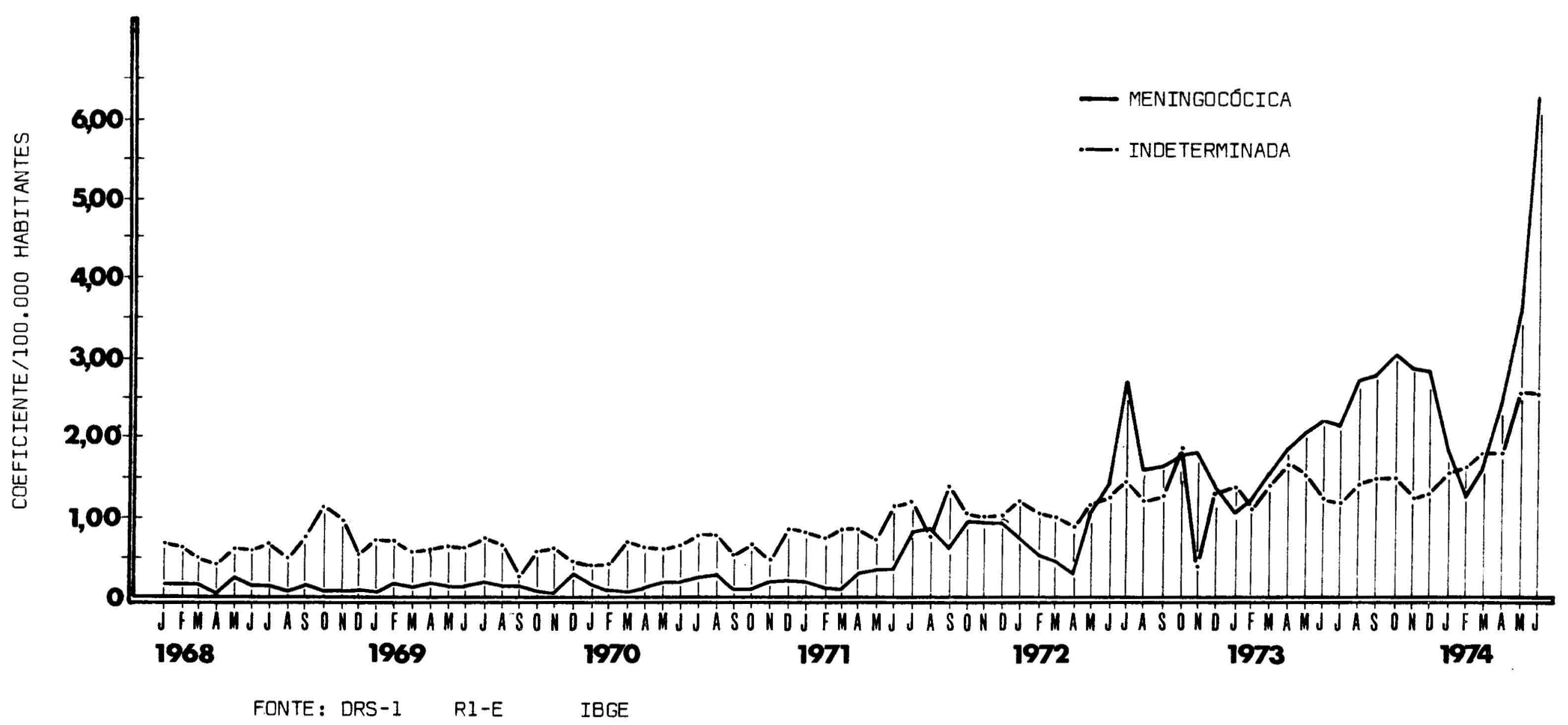


LETALIDADE POR MENINGITE MENINGOCÓCICA E POR MENINGITE DE CAUSA INDETERMINADA NO MUNICIPIO DE SAOO PAULO NO PERIODO DE 1968 - 1974 (MEDIDA EM PORCENTAGEM)

\begin{tabular}{l|c|c|c|c|c|c}
\hline \multirow{2}{*}{ ANOS } & \multicolumn{2}{|c|}{ MENINGI TE MENINGOCOCICA } & \multicolumn{3}{c}{ MENINGI TE CALSA INOE TERMINADA } \\
\cline { 2 - 7 } & Casos & obi tos & Letalidade & Casos & ob itos & Letalidade \\
\hline \multirow{2}{*}{} & 77 & 16 & 20,8 & 434 & 178 & 41,0 \\
1968 & 88 & 12 & 13,6 & 409 & 172 & 42,0 \\
1969 & 122 & 15 & 12,3 & 452 & 146 & 32,3 \\
1970 & 472 & 43 & 10,4 & 729 & 230 & 31,5 \\
1971 & 1015 & 82 & 8,1 & 955 & 267 & 27,3 \\
1972 & 1799 & 124 & 6,9 & 1132 & 237 & 20,9 \\
1973 & 1205 & 100 & 8,3 & 845 & 59 & 7,0 \\
$1974 *$ & & & & & \\
\hline
\end{tabular}

(*) Dados atē junho

FONTE: DRS-1 RT-E 
2. Distribuição cronológica dos casos

De acordo com a que está expresso na Tabela no 1 e Tráfica $\Pi^{0}$ 3, a incidência mensal da meningite meningocácica no Mu nicípio de São Paula elevou-se acima dos níveis esperados a partir de abril de 1971, ocorrendo nesse ano 2 picos, nos mesea de julho e outubro.

Em 1972 abservou-se um pico mais acentuada em julho e outro menor em outubro-novembro. Em 1973, desde janeiro, verifí cou-se uma elevaçãa quase constante até outubro, com grande queda nos meses seguintes.

Em 1974 as coeficientes de morbidade sofreram, a partir de abril, uma elevação que em maio e junho se tornou abrupta。 Nos anos de 1971, 1972 e 1973, perfodo epidêmica, após a a日 censão ocorrida nos meses de inverno e primavera, os coef $\underline{1}$ cientes de morbidade não desceram, nos meses de verãa, ana níveis observados no ano anterior, indicando uma tendência de ascensão da epidemia. Parém, em fevereira e marçá de 1974, ocorreu uma queda até os níveis encontrados em 1973 (em março, o coeficiente chegou a ger menor), sugerindo uma tendência de estabilização. No entanta, a partíi de abril de 1974, a elevação foi acentuada; Em junho, a coeficiente atingido foi mais de duas vezes o maior coeficiente mensal do ano anterior [3,02/100.aco habs. em outubro de 1973]。

Na Tabela nQ 6 observa-se a evolução semanal, na Grande São Paulo, da meningite determinada pelo meningococo sorogrupo A e C, evidenciando a rápida ascensão da primeira. 0 aumen to ecentuado dos casos em maio e junho é consequente à su perposiçãa das duas epidemias. 


\section{TABELA NO 4}

DISTRIBUIÇAO MENSAL DA MORBIDADE POR MENINGITE MENINGOCOCICA *

NO MUNICIPIO DE SAO PAULO NO PERIODO DE 1961 - 1971

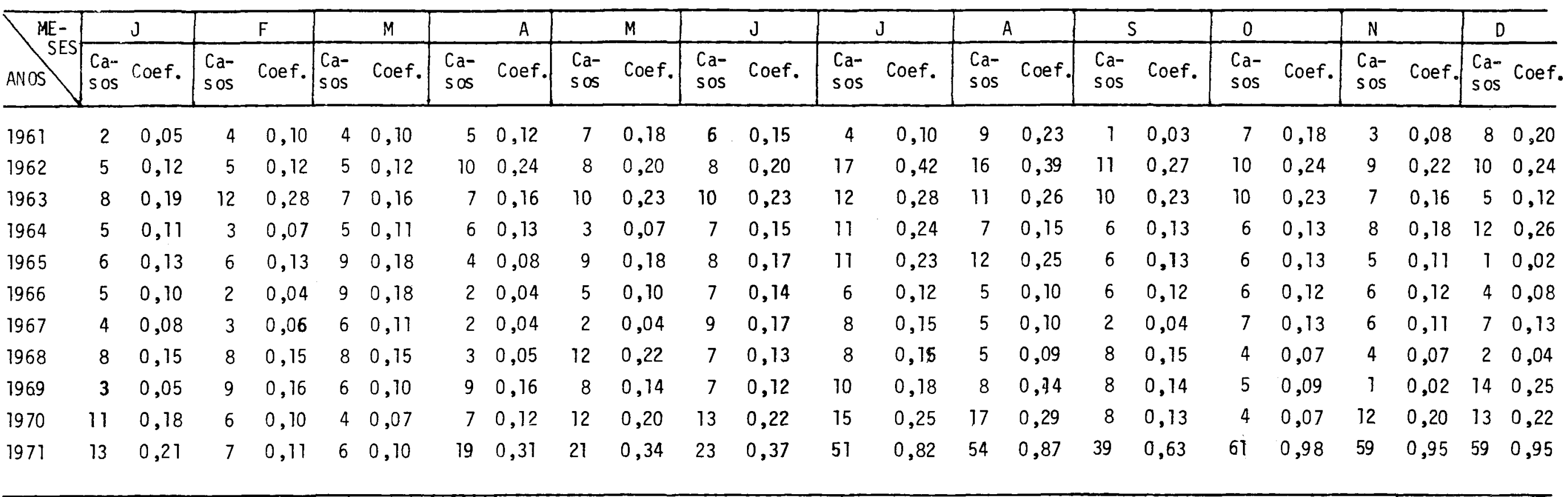

FONTE: RT-E DRS-1

* Meningites Meningocócicas, por diplococos gram- e meningococemias D.E.S.E.P.

Coef. $=$ Coeficiente por 100.000 habitantes 
TABELA NQ 5

MORBIDADE MENSAL POR MENINGITE MENINGOCOCICA NO: MUNICIPIO DE SÃO PAULO

DIAGRAMA DE CONTROLE PARA 1971 BASEADO NO PERTODO DE 1961-1970

\begin{tabular}{|c|c|c|c|c|c|c|c|c|c|c|c|c|}
\hline $1961-1970$ & JAN & FEV & MAR & ABR & MAI & JUN & JUL & $A G O$ & SET & OUT & NOV & $D E Z$ \\
\hline $\bar{x}$ & 0,12 & 0,12 & 0,13 & 0,11 & 0,16 & 0,17 & 0,21 & 0,20 & 0,14 & 0,14 & 0,13 & 0,16 \\
\hline$\sigma x$ & 0,05 & 0,06 & 0,04 & 0,06 & 0,06 & 0,04 & 0,09 & 0,09 & 0,07 & 0,06 & 0,06 & 0,07 \\
\hline $\bar{x}+1,960$ & 0,22 & 0,24 & 0,21 & 0,23 & 0,28 & 0,25 & 0,39 & 0.38 & 0,28 & 0,26 & 0,25 & 0,30 \\
\hline $\bar{x}-1,960$ & 0,02 & - & 0,05 & $-0,01$ & 0,04 & 0,09 & 0,03 & 0,02 & - & 0,02 & 0,01 & 0,02 \\
\hline
\end{tabular}

FONTE: RI-E DRS-I

D.E.S.E.P. 


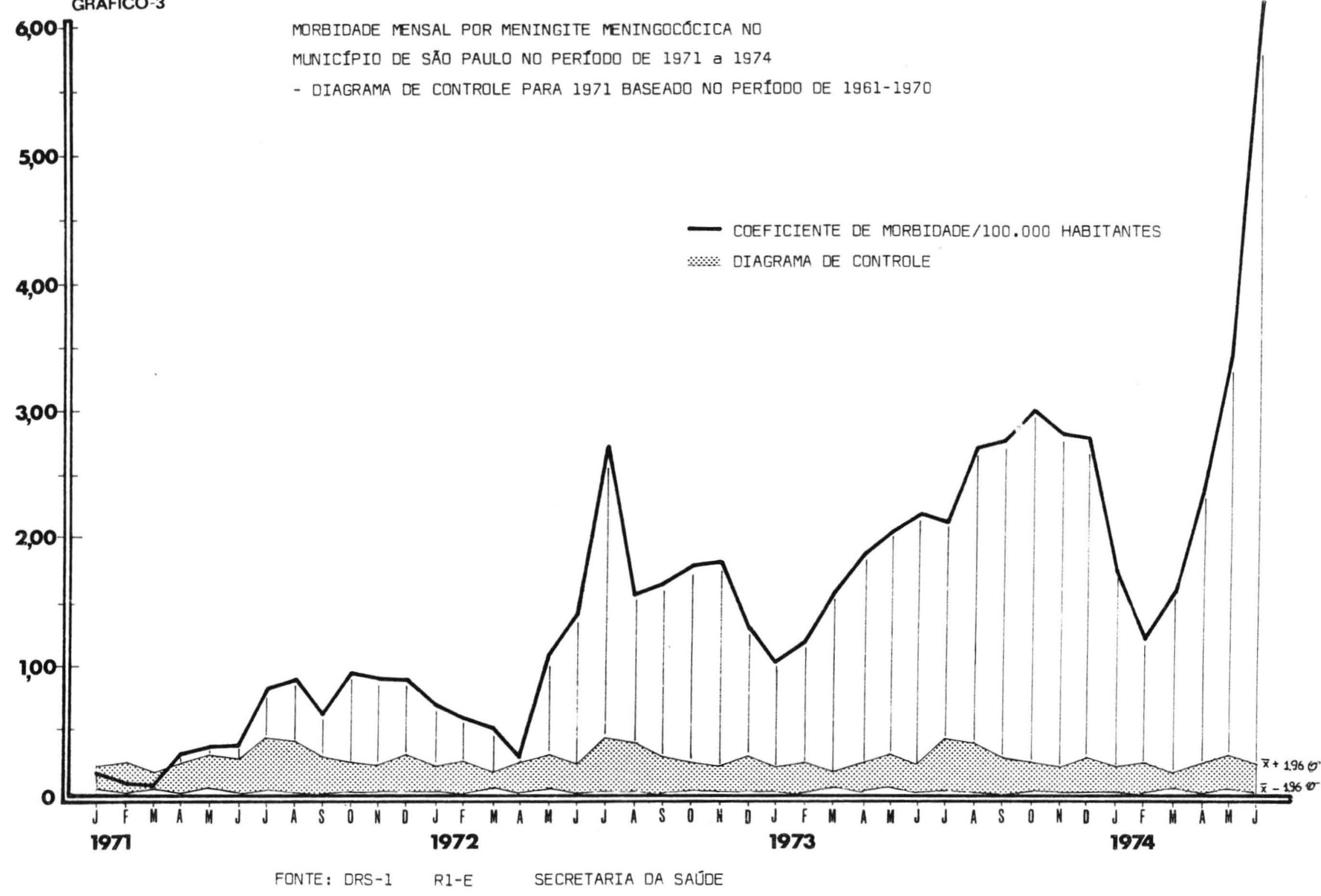


TABELA No 6

EVOLUÇÃO SEMANAL* DAS MENINGITES MENINGOCOCICAS SOROGRUPO A E SOROGRUPO C NA REGIAO DA GRANDE SAOO PAULO, NO PERIODO DE 18 DE ABRIL A 3 DE

JULHO DE 1974.

\begin{tabular}{|c|c|c|c|c|c|c|c|c|c|c|}
\hline \multirow{2}{*}{ SEMANAS } & \multicolumn{2}{|c|}{ SOROGRUPO C } & \multicolumn{2}{|c|}{ SOROGRUPO A } & \multicolumn{2}{|c|}{ NAOO TIPAVEL } & \multicolumn{2}{|c|}{$\mathrm{AeC}$} & \multicolumn{2}{|c|}{ TOTAL } \\
\hline & Casos & $\%$ & Casos & $\%$ & Casos & $\%$ & Casos & $\%$ & Casos & $\%$ \\
\hline 18.4 a 24.4 & 58 & 92,0 & 5 & 8,0 & - & - & - & - & 63 & 100,0 \\
\hline 25.4 a 1.5 & 61 & 98,4 & - & - & 1 & 1,6 & - & - & 62 & 100,0 \\
\hline 2.5 a 8.5 & 24 & 48,0 & 16 & 32,0 & 10 & 20,0 & - & - & 50 & 100,0 \\
\hline 9.5 a 15.5 & 30 & 45,4 & 32 & 48,5 & 4 & 6,1 & - & - & 66 & 100,0 \\
\hline 16.5 a 22.5 & 29 & 37,2 & 46 & 59,0 & 3 & 3,8 & - & - & 78 & 100,0 \\
\hline 23.5 a 29.5 & 25 & 28,7 & 62 & 71,3 & - & - & - & - & 87 & 100,0 \\
\hline 30.5 a 5.6 & 29 & 38,7 & 46 & 61,3 & - & - & - & - & 75 & 100,0 \\
\hline 6.6 a 12.6 & 36 & 37,5 & 56 & 58,3 & 4 & 4,2 & - & - & 96 & 200,0 \\
\hline 13.6 a 19.6 & 31 & 27,9 & 76 & 68,5 & 4 & 3,6 & - & - & 111 & 100,0 \\
\hline 20.6 a 26.6 & 25 & 21,6 & 71 & 61,2 & 20 & 17,2 & - & - & 116 & 100,0 \\
\hline 27.6 a 3.7 & 17 & 14,5 & 83 & 71,0 & 17 & 14,5 & - & - & 117 & 100,0 \\
\hline
\end{tabular}




\section{Distribuicgão geográfica dos casos}

De ecorco com a que está expresso na Tabela 7, no perfodo pré-epidêmico, de 1968-1970, já se observava nos distritos sanitários de Santo Amaro, Nossa Senhora do 0 a São Miguel Pauliata, maior morbidade. No primeiro ano de epidemia, Santo Amaro, Butantã a Nogsa Senhora do 0 foram os diatrî tos sanitários mais atingidos pela epidemia. Na entanto ve rificou-8e maior aumento relativo dos casps em relação ao perfodo anterior no distrito senitárío do Butantã ( 9 veze日 ma18), Belenzinho (7 vezeg mais) e Santo Amaro(5 vezes maig).

Em 1972 os maiores coeficientes do morbidade ocorreram em Santo Amaro, São Miquel Paulista a Jabaquara. 0 maior au mento relativo ao ano anterior ocorreu em Santo Amaro, no Jabaquara a na Lapa.

Em 1973, os malores coeficientes de morbidade ocorreram em Santo Amaro, São Miguel Pauliata e Lapa. 0 maior aumento relativo ao ano antertor ocorreu em Santo Amaro, São Miguel Paulista e Nossa Senhora da 6 .

Em 1974, até junho, a maior morbidade da moléstia foi atin gica pelos distritos sanitários da Lapa, Santa Amaro в Bu 
tantã. Foi na Lapa, Butantã e Nossa Senhora do 6 que ocoI reu o maior aumenta relativo.

Durante tada a evolução da epidemia pelo meningococo eoro grupo C, o distrito sanitário mais atingido foi o de Santo Amaro, seguido de São Miguel Paulista e Lapa. Eases locais estão situados na periferia do Município a apresentam menor densidade demográfica (Tabela no 8 e Gráfico no 4). Fica evidente, por esse gráfico, que a epidemia atingiu maís os distritos sanitários periféricos. Santa Cecília, que apre senta a maior densidade demográfica e está na zona mais cen tral, é o distrito sanitário menos atingido. No primeiro semestre de 1974, quando já es havia constatado a epidemia pelo mentingococo soragrupo $A$, verificau-8e maior marbidade nos distritos sanitários da Lapa, Butantã a Santo Amara, li mitrofas do Municlpio de Osasco, onde presumivelmente es iniciou a epldemia por meningococo sorogrupo $A$. 
TABELA NO 7

MORB IDADE POR MENINGITE MENINGOCOCICA NOS DISTRITOS SANITARIOS DO

MUNICTPIO DE SAO PAULO NO PERTODO DE 1968 - 1974

\begin{tabular}{|c|c|c|c|c|c|c|c|c|c|c|}
\hline \multirow{2}{*}{ Distritos Sanitärios } & \multicolumn{2}{|c|}{ 1968-70 } & \multicolumn{2}{|c|}{1971} & \multicolumn{2}{|c|}{1972} & \multicolumn{2}{|c|}{1973} & \multicolumn{2}{|c|}{$1974\left(^{*}\right)$} \\
\hline & Casos & Coef.* & Casos & Cof. $\star \star$ & Casos & Coef. $\star \star \star$ & Casos & Coef. $* \star$ & Casos & Coef. $* \star$ \\
\hline \multirow{3}{*}{$\begin{array}{l}\text { Rl - Santa Cecília } \\
\text { Belenzinho } \\
\text { Vila Mariana }\end{array}$} & 21 & 1,2 & 27 & 4,3 & 54 & 8,5 & 111 & 17,1 & 88 & 13,3 \\
\hline & 10 & 1,1 & 25 & 7,9 & 36 & 11,3 & 58 & 18,3 & 30 & 9,4 \\
\hline & 14 & $i, 3$ & 16 & 4,3 & 39 & 10,2 & 75 & 19,1 & 33 & 8,1 \\
\hline \multirow{3}{*}{$\begin{array}{l}\text { RT-2 Vila Maria } \\
\text { Penha de França } \\
\text { S.Miguel Paulista }\end{array}$} & 8 & 1,4 & 8 & 4,0 & 26 & 12,8 & 46 & 27,6 & 27 & 12,2 \\
\hline & 26 & 1,3 & 22 & 3,0 & 85 & 11,2 & 150 & 19,1 & 73 & 8,9 \\
\hline & 38 & 2,1 & 47 & 6,7 & 134 & 17,9 & 297 & 37,1 & 160 & 18,7 \\
\hline \multirow{2}{*}{$\begin{array}{l}\text { RI-3 Jabaquara } \\
\text { Vi la Prudente }\end{array}$} & 22 & 1,8 & 28 & 6,2 & 84 & 17,7 & 118 & 23,6 & 61 & 11,7 \\
\hline & 2] & 1,4 & 32 & 5,8 & 95 & 16,5 & 130 & 21,7 & 73 & 11,7 \\
\hline RT-4 Tucuruvi & 31 & 1,9 & 31 & 5,3 & 78 & 12,8 & 128 & 20,0 & 85 & 12,7 \\
\hline N.Senhora do $\delta$ & 27 & 2,1 & 37 & 8,0 & 70 & 14,5 & 136 & 26,9 & 121 & 22,8 \\
\hline Lapa & 17 & 1,9 & 17 & 5,3 & 56 & 16,6 & 98 & 27,9 & 148 & 40,4 \\
\hline Butantã & 9 & 1,0 & 30 & 9,4 & 50 & 15,0 & 78 & 22,3 & 89 & 24,3 \\
\hline Santo Amaro & 43 & 2,8 & 92 & 15,4 & 208 & 32,6 & 374 & 54,3 & 217 & 29,4 \\
\hline TOTAL & 287 & 1,7 & 412 & 6,6 & 1015 & 15,6 & 1799 & 26,5 & 1205 & 17,0 \\
\hline \multirow[t]{2}{*}{$\begin{aligned} \text { FONTE: } & \text { DRS-1 RT-E } \\
& \text { I.B.G.E. } \\
& \text { D.E.S.E.P. }\end{aligned}$} & & & & . & & & \multicolumn{4}{|c|}{$\begin{aligned} \text { Coef. }{ }^{*}= & \text { coeficiente médio por } \\
& 100.000 \text { habitantes }\end{aligned}$} \\
\hline & & & & & & & \multicolumn{4}{|c|}{$\begin{array}{c}\text { Coef. } * *=\underset{\text { coeficiente por } 100.000}{\text { habitantes }} \\
\text { hatant }\end{array}$} \\
\hline
\end{tabular}


TABELA NO 8

DENSIDADE DEMOGRAFICA E MORBIDADE POR MENINGITE MENINGOCOCICA NOS DISTRITOS SANITARIOS DO MUNICIPIO DE SAOO PAULO NOS PERIODOS DE 1968-1970 E 1971- 1973

\begin{tabular}{|c|c|c|c|c|}
\hline \multirow{2}{*}{ DISTRITOS SANITARIOS } & 1969 & $1968-70$ & 1971 & $1971-73$ \\
\hline & $\begin{array}{l}\text { Dens idade } \\
\text { Demografica }\end{array}$ & $\begin{array}{l}\text { Coef.mëdio } \\
\text { p/ } 100 \text { mi } 1 \\
\text { habitantes }\end{array}$ & $\begin{array}{c}\text { Densidede } \\
\text { Demografica }\end{array}$ & $\begin{array}{l}\text { Coef médio } \\
\text { p/ } 100 \text { mi } 1 \\
\text { habitantes }\end{array}$ \\
\hline Santa Cecîlia & 15.861 & 1,2 & 16.111 & 10,0 \\
\hline Belenzinho & 11.969 & 1,1 & 11.734 & 12,5 \\
\hline Vila Prudente & 10.647 & 1,4 & 11.740 & 14,9 \\
\hline ViTa Maria & 10.026 & 1,4 & 10.920 & 13,0 \\
\hline Jabaquara & 9.476 & 1,8 & 10.758 & 16,1 \\
\hline V. Senhora do $\sigma$ & 8.969 & 2,1 & 10.126 & 16,7 \\
\hline Penha de França & 8.870 & 1,3 & 9.734 & 11,3 \\
\hline Vila Mariana & 6.541 & 1,3 & 6.972 & 11,4 \\
\hline Tucuruvi & 4.350 & 1,9 & 4.869 & 12,9 \\
\hline 3utantã & 4.162 & 1,0 & 4.695 & 15,8 \\
\hline 5ão Miguel Paulista & 3.189 & 2,1 & 3.905 & $2 T, 3$ \\
\hline Lapa & 2.639 & 1,9 & 2.929 & 16,9 \\
\hline janto Amaro & 808 & 2,8 & 1.001 & 35,0 \\
\hline
\end{tabular}

=ONTE: DRS-1 RT-E

$$
\text { I.B.G.E. }
$$

D.E.S.E.P. 
PQR MINIGITE MENINGOCOCICA SEGUNDO OS DISTRITOS SANITARIOS

NO MUNICIPIO DE SAO PAULO NO PERIODO DE 1971 A 1973
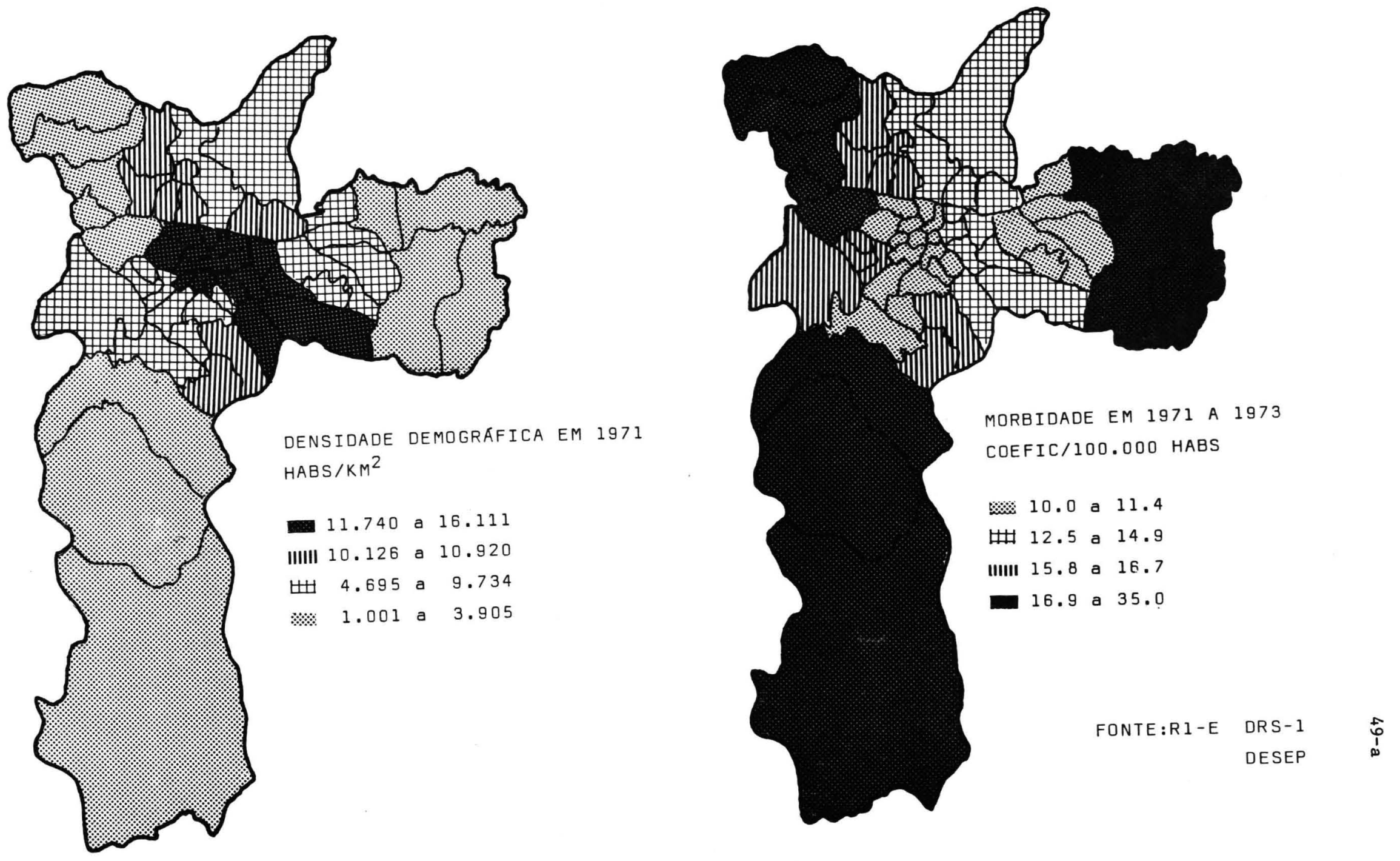
4. Distribuiçãa dos casos por idade

A abservação da Tabela n̊ 9 e Gráfica $n^{Q} 5$ evidencia que, nos períndos pré-epidêmicos e endêmicos, acorreu uma distrî buiçẽo semelhante dos coeficientes de morbidade por grupos etários, isto é; o grupo dos latentes foi o mais atingido, ocarrendo um decréscimo dos coeficlentes à medida que aumen ta a idade. No entanto, relacionando-se a incidência em 1970 a 1973, verifica-se que em alguns grupos etários ocor reu um aumento relativa maior da morbidade: no grupa etário de 15-19 enos fai de 27 vezes, no grupo etíría de 20-24 anos de 21 vezes, no grupo etário de 30-39 anos de 22 vezes e no grupo etário de mais de 50 anos de 46 vezes.

No segundo trimestre de 1974, abserva-se uma distribuição etéria dos casas, diferente de que vinha ocorrendo no trî mestra anterior (Tabela na 10). Verificou-8e uma diminuí çãa na incidência dos casos no grupo etário de $0-10$ anos e um aumento no grupo de mais de 10 anos, bem mais evidente entre 15-29 anos. Isto está relacionado ao aparecimento da epidemia determinada pela meningococo soragrupo $A$, que de infcio atingiu mais o grupo acima dos 10 anos de idade. Eg se fato está expresso na Tabela no 11 e Gráfico no 6. 
TABELA No 9

MORBIDADE POR MENINGITE MENINGOCÓCICA SEGUNDO A IDADE NO MUNICTPIO DE SAO PAULO, NO PERTODO DE 1968 a 1974.

\begin{tabular}{|c|c|c|c|c|c|c|c|c|c|c|c|c|c|c|}
\hline \multirow{2}{*}{$\begin{array}{c}\text { IDADE } \\
\text { (EM ANOS) }\end{array}$} & \multicolumn{2}{|c|}{1968} & \multicolumn{2}{|c|}{1969} & \multicolumn{2}{|c|}{1970} & \multicolumn{2}{|c|}{1971} & \multicolumn{2}{|c|}{1972} & \multicolumn{2}{|c|}{1973} & \multicolumn{2}{|c|}{1974 * } \\
\hline & Casos & Coef. & Casos & Coef. & Casos & Coef. & Casos & Coef. & Casos & Coef. & Casos & Coef. & Casos & Coef. \\
\hline-1 & 23 & 19,1 & 17 & 13,5 & 30 & 22,9 & 56 & 40,8 & 129 & 89,8 & 206 & 131,5 & 92 & 58,7 \\
\hline $1-4$ & 22 & 4,6 & 31 & 6,3 & 30 & 5,8 & 104 & 19,2 & 259 & 45,8 & 461 & 77,9 & 280 & 45,3 \\
\hline $5-9$ & 6 & 1,0 & 14 & 2,2 & 23 & 3,4 & 92 & 13,2 & 205 & 28,7 & 383 & 50,2 & 237 & 29,8 \\
\hline $10-14$ & 13 & 2,3 & 9 & 1,5 & 18 & 3,0 & 65 & 10,2 & 135 & 20,3 & 244 & 35,1 & 168 & 23,1 \\
\hline $15-19$ & 3 & 0,6 & 8 & 1,4 & 6 & 1,0 & 33 & 5,4 & 94 & 14,6 & 183 & 27,2 & 147 & 21,0 \\
\hline $20-24$ & 4 & 0,7 & 3 & 0,5 & 6 & 1,0 & 31 & 4,9 & 85 & 12,7 & 150 & 21,5 & 187 & 13.9 \\
\hline $25-29$ & 1 & 0,2 & 2 & 0,4 & 5 & 1,0 & 10 & 1,8 & 38 & 6,7 & 60 & 10,1 & & \\
\hline $30-39$ & 2 & 0,2 & 2 & 0,2 & 2 & 0,2 & 12 & 1,3 & 36 & 3,8 & 43 & 4,4 & 44 & 4,3 \\
\hline $40-49$ & 1 & 0,2 & - & - & 1 & 0,2 & 6 & 0,9 & 15 & 2,1 & 29 & 3,9 & 20 & 2,6 \\
\hline $50 e+$ & 2 & 0,3 & 2 & 0,3 & 1 & 0,1 & 3 & 0,4 & 18 & 2,2 & 40 & 4,6 & 30 & 3,3 \\
\hline TOTAL & 77 & 1,4 & 88 & 1,5 & 122 & 2,1 & 412 & 6,6 & 1015 & 15,6 & 1799 & 26,5 & 1205 & 17,0 \\
\hline
\end{tabular}

(*) Dados atē junho

FONTE: DRS-1 RT-E

I.B.G.E.

D.E.S.E.P. 


\section{GRAFICO - 5}

13L5 MORBIDADE POR MENINGITE MENINGOCÓCICA

NO MUNiCfPIO dE SÃo PAULO, SEgundo A IDAdE,

NO PERIODO DE 1968 aO $1^{\circ}$ SEMESTRE DE 1974

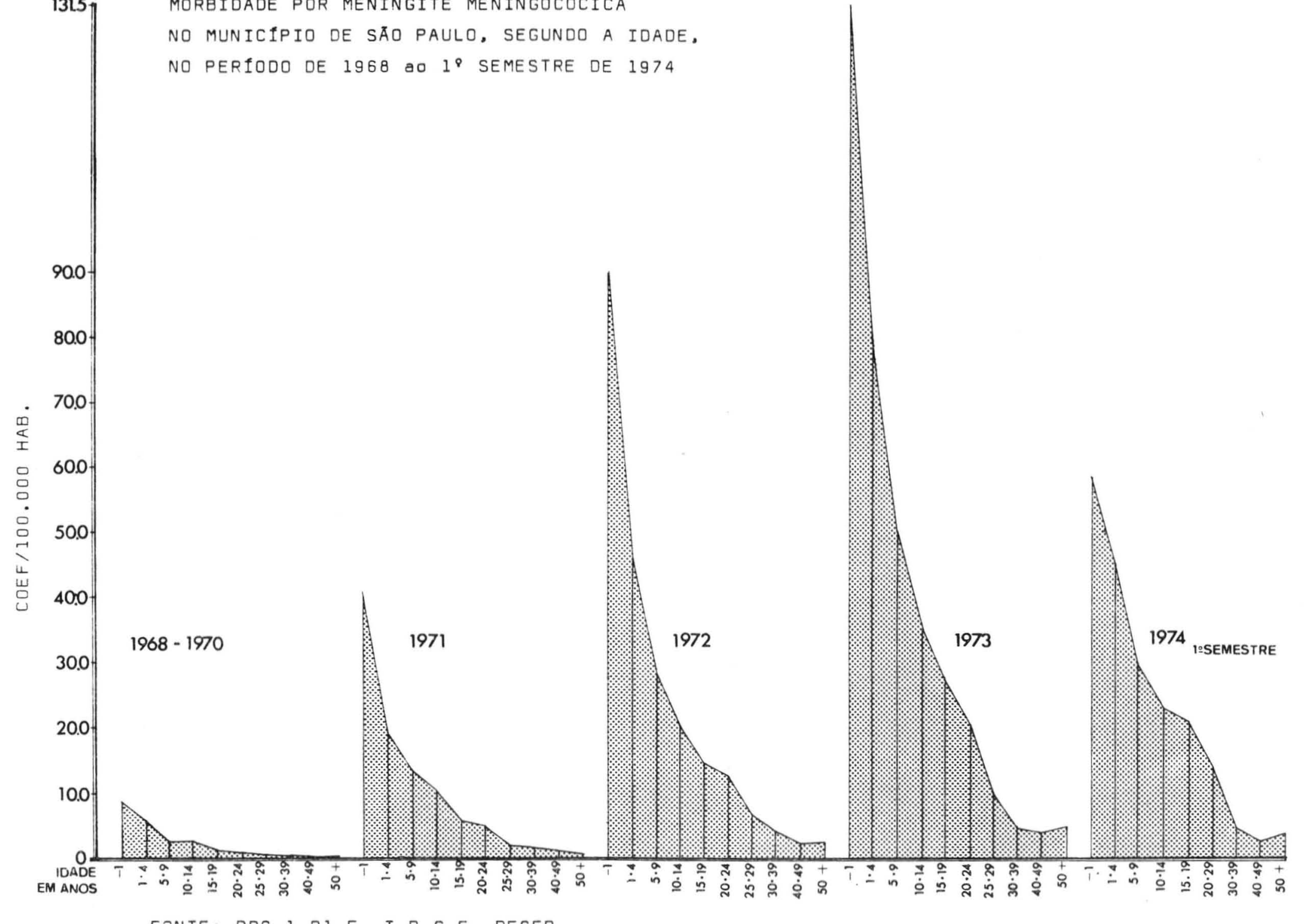


TABELA NQ 10

CASOS DE MENINGITE MENINGOCÓCICA, SEgUNdO A IDADE, NO MUNiCTPIO DE SÃO PAULlO NO PRIMEIRO E SEGUNDO TRIMESTRES DE 1974 (EM PORCENTAGEM)

\begin{tabular}{|c|c|c|c|c|}
\hline Semestres & & & & \\
\hline anos & Casos & $\%$ & Casos & $\%$ \\
\hline-1 & 31 & 9,3 & 61 & 7,0 \\
\hline $1-4$ & 96 & 28,9 & 184 & 21,1 \\
\hline $5-9$ & 80 & 24,1 & 157 & 18,0 \\
\hline $10-14$ & 44 & 13,2 & 124 & 14,2 \\
\hline $15-19$ & 28 & 8,4 & 119 & 13,6 \\
\hline $20-29$ & 38 & 11,4 & 149 & 17,1 \\
\hline $30-39$ & 7 & 2,1 & 37 & 4,2 \\
\hline $40-49$ & 3 & 0,9 & 17 & 1,9 \\
\hline $50+$ & 5 & 1,5 & 25 & 2,9 \\
\hline TOTAL & 332 & 100,0 & 873 & 100,0 \\
\hline
\end{tabular}

FONTE: $\quad$ RI-E

DRS- 1 
DISTRIBUIÇÃO PERCENTUAL DOS CASOS DE MENINGITE MENINGOCOCICA

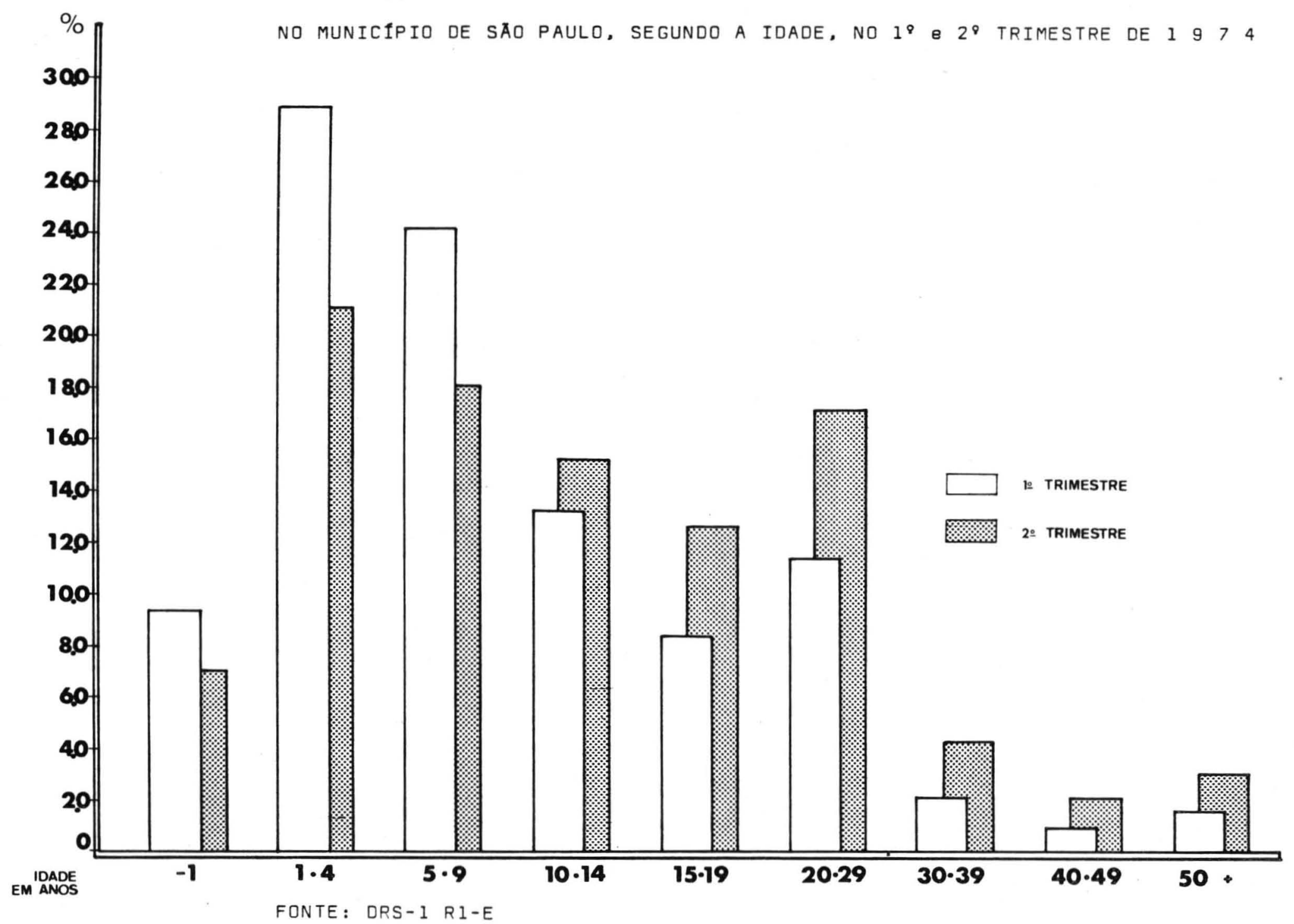


TABELA NQ 11

DISTRIBUI ÇAO DOS CASOS DE MENINGITE MENINGOCŌCICA SEGUNDO A IDADE NA GRANDE SÃO PAULO NOS MESES DE JULHO DE 1971 A MAIO DE 1974 *

\begin{tabular}{l|c|c|c|c}
\hline \multirow{2}{*}{$\begin{array}{l}\text { IDADE EM } \\
\text { ANOS }\end{array}$} & \multicolumn{2}{|c|}{ GRUPO C- JULHO 71 } & \multicolumn{3}{|c|}{ GRUPO A - MAIO 74 } \\
\cline { 2 - 5 } & NQ CASOS & $\%$ & NQ CASOS & $\%$ \\
\hline
\end{tabular}

$\begin{array}{rrrrr}-1 & 7 & 9,9 & 0 & 0 \\ 1-4 & 22 & 31,0 & 14 & 9,8 \\ 5-9 & 18 & 25,4 & 26 & 17,7 \\ 10-14 & 8 & 11,3 & 27 & 18,4 \\ 15-19 & 4 & 5,6 & 20 & 13,6 \\ 20-24 & 6 & 8,4 & 35 & 23,8 \\ 25-29 & 1 & 1,4 & 8 & 5,4 \\ 30-39 & 4 & 5,6 & 9 & 6,1 \\ 40-49 & 0 & 0 & 6 & 4,1 \\ +50 & 1 & 1,4 & 2 & 1,4 \\ \text { TOTAL } & 71 & 100,0 & 147 & 100,0\end{array}$

FONTE: R1-E DRS-1 Secretaria de Saūde de São Paulo Ins ti tuto Adolfo Lutz

(*) Meses en que foi verificado o início da epidemia por meningoco grupo $\mathrm{C}$ e meningococo grupo $\mathrm{A}$, respectivamente. 
Distribuiçãa dos casos por sexa

Nos períndos pré-epidêmico e epidêmico a sexa masculino fai a mais atingido, e de farma mais evidente nos anos epidêmi cos de 1973 e 1974 (até junho).

TABELA NQ 12

MOREIDADE PDR MENINGITE MENINGOCÓCICA NQ MUNICIPIO DE SÃD PAULO, SEGUNDO ㅁ SEXO ND PEPIDUDD $\underline{D E} 1968-1974$

\begin{tabular}{|c|c|c|c|c|c|c|c|c|c|c|}
\hline \multirow{2}{*}{ SEXO } & \multicolumn{2}{|c|}{$1968-70$} & \multicolumn{2}{c|}{1971} & \multicolumn{2}{c|}{1972} & \multicolumn{2}{c|}{1973} & \multicolumn{2}{c|}{1974} \\
\cline { 2 - 10 } & cas. & cogf. & ca日. & coef. & cas. & coef. & cas. & coef. & cas. & coef. \\
\hline Masc. & 147 & 1,7 & 219 & 7,2 & 533 & 16,7 & 972 & 29,1 & 702 & 20,2 \\
\hline Fam. & 140 & 1,6 & 193 & 6,1 & 482 & 14,6 & 827 & 23,9 & 503 & 13,9 \\
\hline TOTAL & 287 & 1,7 & 412 & 6,6 & 1015 & 15,6 & 1799 & 26,5 & 1205 & 17,0 \\
\hline
\end{tabular}

FONTE: DRS-1 R1-E I.B.G.E. coef.= coeficiente por 100.000 habitantes 
6. Letalidade

6.1 Distribuição cronológica

A letalidade dos casos notificados ao Serviço de Epide miologia da ORS-1, apresentou um decréscimo de 1968 a 1973. (Tabela $n^{\mathrm{Q}} 3$ )

Dcorreu nos anos epidêmicos uma variação sazonal da leta lidade, isto é, nas meses quentes um aumento em relação aus meseg frios, ad contrário da que se observou com a morbidade。A Tabela $n^{0} 13$ e o Gráfica $n^{0} 7$ ilustram eg se fato.

6.2 Distribuição por idade

No primeiro semestre de 1974, acorreu uma elevação eví dente em quase todos os grupos etários (Tabela no 14). A letalidade no período pré-epidêmico de 1968-1970 foi maior no grupo abaixa de 1 ano e de 30-39 anas, e no pe Iíodo epidêmico de 1971-1974 foi maior no grupo abaixa de 1 ano e maior de 50 anos de idade.

Nesse períada a que se observa é uma diminuiçãa da leta lidade até os 19 anos e, a partir daf, uma ascensão. Ds grupos etários que apresentaram maiar aumento relativo de marbidade entre 1970 e 1973 (15 a 19 anos, 30 a 39 anos e mais de 50 anos) tiveram sua letalidade diminuida no períndo considerado.

6.3 Distribuição por sexo

Nos perílodas consideradas epidêmicos e pré-epidêmico (Te bela ne 15) fai maior a letalidade no sexa masculino. 
TABELA NO 13

MORBIDADE E LETALIDADE MEDIANAS QUADRIMESTRAIS POR MENINGITE MENINGOCOCICA NO MIINICIPIO DE SÄO PAULO NO PERTODO DE JULHO DE 1971 A JUNHO DE 1974 (MEDIDAS RESPECTIVAMENTE POR COEFICIENTES POR 100.000 HABITANTES E EM PORCENTAGENS)

\begin{tabular}{|c|c|c|c|c|}
\hline \multirow{2}{*}{ QUADRIMESTRES } & \multicolumn{2}{|c|}{ MORB I DADE } & \multicolumn{2}{|c|}{ LETALIDADE } \\
\hline & COEFICIENTES & $\begin{array}{l}\text { VARIACAO } \\
\text { PERCENTUAL }\end{array}$ & $\%$ & $\begin{array}{r}\text { VARIACAO } \\
\text { PERCENTUAL }\end{array}$ \\
\hline 10 - julho a outubro 1971 & 0,85 & 100,0 & 8,6 & 100,0 \\
\hline 20 - novembro 1971 a fevereiro 1972 & 0,85 & 100,0 & 11,1 & 130,0 \\
\hline 30 - março 1972 a junho de 1972 & 0,78 & 90,0 & 10,5 & 120,0 \\
\hline 40 - julho 1972 a outubro 1972 & 1,73 & 200,0 & 6,3 & 70,0 \\
\hline 50 - novembro 1972 a fevereiro 1973 & 1,31 & 150,0 & 7,4 & 90,0 \\
\hline 60 - março 1973 a junho 1973 & 1,98 & 230,0 & 6,3 & 70,0 \\
\hline 70 - jultho 1973 a outubro 1973 & 2,77 & 330,0 & 6,5 & 70,0 \\
\hline 80 - novembro 1973 a fevereiro 1974 & 2,35 & 280,0 & 8,4 & 90,0 \\
\hline 90 - março 1974 a junho 1974 & 3,03 & 360,0 & 7,7 & 80,0 \\
\hline
\end{tabular}

FONTES $R_{1}-E$ DRS-1 D.E.S.E.P.


GRÁFICO 7

LETALIDADE E MORBIDADE

MEDIANAS QUADRIMESTRAIS POR

MENINGITE MENINGOCÓCICA NO MUNICIPIO DE SÃO PAULO

ND PERIODO DE $1^{9}$ DE JULHO DE 1971 A 30 DE JUNHO DE 1974

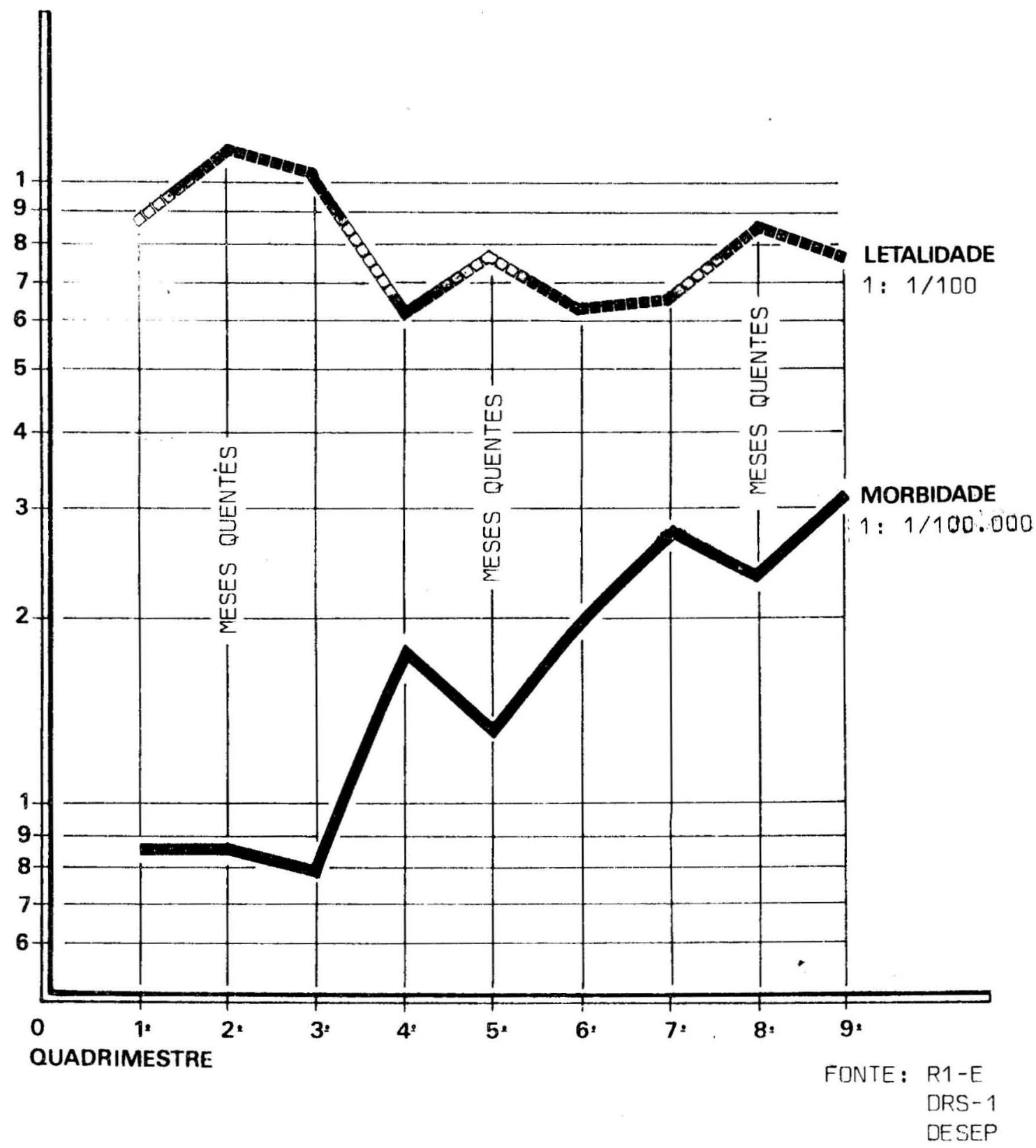


TABELA № 14

LETALIDADE POR MENINGITE MENINGOCOCICA SEGUNDO A IDADE, NO MUNICIPIO DE SAOO PAUL.O, NO PERTODO DE 1968 - 1974*

\begin{tabular}{|c|c|c|c|c|c|c|c|c|c|c|c|c|c|c|c|}
\hline \multirow{2}{*}{$\begin{array}{c}\text { IDA } \\
\text { (EM ANOS) } \\
\end{array}$} & \multicolumn{3}{|c|}{$1968-70$} & \multicolumn{3}{|c|}{1971} & \multicolumn{3}{|c|}{1972} & \multicolumn{3}{|c|}{1973} & \multicolumn{3}{|c|}{$1974 *$} \\
\hline & cas. & obit. & $\%$ & cas. & obit. & $\%$ & cas. & obit & . $\%$ & cas. & obit. & $\%$ & cas. & obit. & $\%$ \\
\hline-1 & 70 & 19 & 27,1 & 56 & 10 & 17,9 & 129 & 16 & 12,4 & 206 & 31 & 15,0 & 92 & 19 & 20,6 \\
\hline $1-4$ & 83 & 10 & 12,0 & 104 & 16 & 15,4 & 259 & 31 & 12,0 & 461 & 36 & 7,8 & 280 & 25 & 8,9 \\
\hline $5-9$ & 43 & 2 & 4,6 & 92 & 6 & 6,5 & 205 & 7 & 3,4 & 383 & 14 & 3,6 & 237 & 13 & 5,5 \\
\hline $10-14$ & 40 & 4 & 10,0 & 65 & 1 & 1,5 & 135 & 5 & 3,7 & 244 & 7 & 2,9 & 168 & 10 & 5,9 \\
\hline $15-19$ & 17 & 2 & 11,8 & 33 & 1 & 3,0 & 94 & 1 & 1,1 & 183 & 9 & 4,9 & 147 & 5 & 3,4 \\
\hline $20-29$ & 21 & 3 & 14,3 & 41 & 6 & 14,6 & 123 & 12 & 9,8 & 210 & 13 & 6,2 & 187 & 17 & 9,1 \\
\hline $30-39$ & 6 & 2 & 33,3 & 12 & 2 & 16,7 & 36 & 3 & 8,3 & 43 & 5 & 11,6 & 44 & 3 & 6,8 \\
\hline $40-49$ & 2 & - & - & 6 & - & - & 15 & - & - & 29 & 3 & 10,3 & 20 & 3 & 15,0 \\
\hline $50+$ & 5 & 1 & 20,0 & 3 & 1 & 33,3 & 18 & 7 & 38,9 & 40 & 6 & 15,0 & 30 & 5 & 16,7 \\
\hline TOTAL & 287 & 43 & 15,0 & 412 & 43 & 10,4 & 1015 & 82 & 8,1 & 1799 & 124 & 6,9 & 1205 & 100 & 8,3 \\
\hline
\end{tabular}

FONTE: RT-E DRS-1
(*) Dados atē junho

cas. = casos

obit. = obitos 
TABELA No 15

LETALIDADE POR MENINGITE MENINGOCOCICA SEGUNDO O SEXO, MUNICIPIO DE SÃO PAULO NOS PERIOdOS 1968-70 E 1971-1974* (MEDIDA EM PORCENTAGEM)

\begin{tabular}{l|c|c|c|c|c|c}
\hline & \multicolumn{3}{|c|}{$1968-1970$} & \multicolumn{3}{c}{$1971-1974^{\star}$} \\
\cline { 2 - 6 } sexo & casos & óbitos & letalidade & casos & óbitos & letalidade \\
\hline \multirow{2}{*}{$\begin{array}{l}\text { Masculino } \\
\text { Feminino }\end{array}$} & 147 & 25 & 17,0 & 2.426 & 211 & 8,7 \\
TOTAL & 140 & 18 & 12,9 & 2.005 & 138 & 6,9 \\
\hline
\end{tabular}

FONTE: $\quad$ RT-1

(*) Dados atē junho

DRS-1 
$V I I-\underline{\text { DISCUSSÃO }}$

1. Eclosão e duraçãan da ep epidemia

Apesar do progresso do conhecimento sobre a imunidade natü ral ao meningococo, não existe, até hoje, uma explicação clara para a súbito aparecimento de uma epidemia de menin gite meningocácica. Em um grande centro urbano como sãa Paulo, alguns fatores podem ter atuado:

\section{Mìgracãan}

0 enorme crescimento industrial da área metropolitana de 5ão Paulo nas últimas décadas só foi possível devido ao mo vimenta migratáría das populações de áreas rurais ou cida des menorea, que se dirigiram para a Grande São Paulo à pracura de melhores oportunidades de trabalho,proporcionan do ès industrias mão-de-obra abundante e barata。

A migração de 1.227.480 pessuas foi responsável por 56 por cento do aumenta populacional do Município de São Paulo na década de 1960-1970 (60).

Existem poucos dados disponíveis que permitam caracterizar essa população migrante, assim como os locais onde ela pre ferencialmente se instalou. Um levantamento amostral rea lizada por Maria Lucia Saboll (64) indica que 44,5\% dos mi grantes do Município de 5ão Paulo tem sua origem no inte rír do Estado de 5ãa Paulo; 35,5\% nos estados de Minas Ge rais e do Nordeste; $19.9 \%$ no exterior e outros estados. Em 
bora essa população não seja homogênea em relação a renda, ingtrução. idade an chegar e ocupação, a maioria tem nível de instruçãa de curso primério incompleto, idade média em tarno dos 20 anos e exerce ocupação nãa qualificada com renda média mensal de um salário mínimo. O conaumo diário de calorias e proteinas desses migrantes está presumivel. mente abaixa dos níveis mínimos desejáveis. Um estuda do nfvel alimentar da população trabalhadora da cidade de Sãa Paulo, realizado em 1973 pelo Departamento Intersindical 由 Estatística e Estudos Socioeconömicos (DIEESE) (17), mastra um consumo médio diário de 2.113 calorias e 57,1g de prọ teina nos indivíduos com renda abaixa de 500 cruzeiros.

Calcula-8e que um grande contingente de população migrante fol regidir nos bairros periféricos do Municlpio, preferí dos pela população de menor renda e ande ja moravam paren tes e amigos.

Pesquiaag realizadas por Leser e Barbosa (1972) (49), reve lam Indices diversos de crescimenta demográfico na década de 1960 a 1970 em tres diferentes áreas do Municipio de São Paulo. Na área central, servida quase que tatalmente por rede de água e esgoto, o crescimento populacional fai de 6,9\%; na zona intermediária, com sistema de abastecimento de água atingindo apenas algumas regiões e rede de esgo tos deficitária, a crescimento fai de 62,9\%; na zona perí férica, com apenas algumas residências ligadas à rede de 
água e a maioria servinda-se de fassas, o crescimento fai de $145,2 \%$.

Ds migrantes, vivendo em condições de aglomeração habitạ cional, mal alimentados, exercendo trabalho braçal com maior estafa física, não aclimatados, submetidos a stress físico e emocional pelas diferenças de vida na metrópole e apresentando possivelmente um estado imunolágico de me nor defesa ao meningococo, constituiram um terreno ótima para a instalação e propagação da moléstia meningocócica.

Esistem referências na literatura sobre a relação entre os movimentos migratórios e as epidemias de meningite meningo cócica. Hedrich (40) relacionou as quatro grandes epide mias nos Estados Unidos, ocorridas em 1918, 1929,1935-1936 e 1942-1943 a um movimento populacional das áreas rurais para áreas mais congestionadas, determinada pela migração de mão-de-obra dos campos para as cidades, em épocas de grande atividade industrial, ou pelo recrutamento militar nos períodos de guerra. Serré-Boisseau (63), em um estudo sobre a meningite meningocócica na França, no períado de 1960 a 1972, abservou uma significativa incidência nas pㅁ pulações migrantes, francesas ou não, social e econamic日 mente desfavorecidas.

Nas campos de recrutas militares das Estados Unidos a inci dência da maléstia sempre foi significativamente maior nos recrutas recém-chegados do que nos com maior tempo de per 
manëncia. Atraves das trabalhos de Heist(4l) e Goldschnei der e colaboradores (30) (31) sobre a imunidade natural ao meningococo, ficou demonstrado que ela é predominantemente do tipo humoral. 0 aparecimento dos anticorpos far-se-ia a partir das canstantes calonizações no nasofaringe de ce pas patogënicas a nãa da bactéria. A populaçãa recentẹ mente mlgrante, procedente da zona rurel au de cidades me norea, teria menar oportunidade de contato com as cepas de meningococo circulantes nos períodos endëmicos, e por isso maior suscetibilidade à moléstia que a população residente.

Goldachneider e colaboradores (1968) (30), en um estuda praspectivo de 14.744 recrutas militares nos Estados Lhidos durante seu treinamento militar, verificaram que 94,4\% dos sorog dos 54 recrutas que adquiriram meningite meningocóci ca não eram bactericidas para o meningococo na primelra a日 mena de treinamento.Entre as sadios, sá 17,8\% tinham so ros bactericidas para o meningocaca nessa primeira semana. Um levantamento feito através das fichas de investigação epidemiológica sobre a incidência da moléstia na atual epí demia de São Paula, comparando a grupo recentemente migran te a a papulaçãa em geral, seria apartuno no sentida de $\underline{e}$ lucidar essa hipótese. A epidemia de meningococo grupo $A$, que se iniciou provavelmente no Município de Osasca, local para ande afluem grande número de migrantes,possibilitaria uma investigaçãa dessa natureza. 
Moblilidade de popplieção:

Além da migração, existe ainda a considerar a constante mo vimentação de população periférica do municipio, de suas realdênclas para as locaia de trabalha, geralmente maia centraia, assim como da população residente em outros muni clpios da Grende 5äo Paula para o Municlpio de São Paula , onde trabalha. Esaa movimentação díaria, em trangportea superlotados, proporciona condiçōes multo favorávela $\dot{a}$ transmissão da moléstia e à sua propagação a locais mals distantes.

Esses fatores, aliados à densidade da populaçãa da Municí pio, certamente favorecerão uma duraçãa mais longa da epí demia na sue evolução natural.

2. Meninqites Meningocócicas ㅂ por causas indeterminadas A falta de identificação dos agentes etiológicos das menin gites está ligada à não realização de exames adequados, à realização desses exames em más condiçōes técnicas, ou a uso indiscriminado de antibióticos antes que o doente faça colheita de líquar para exame bacterioscópico e cultura.

Há um paralelismo entre a incidência da meningite meningo cócica e meningites de causas indeterminadas, menos ev 1 dente a partir de 1972. Provavelmente, em um bom número de casos de meningite meningocócica não foi identificada o meningococa, senda eles rotulados camo meningites de causa indeterminada. 
Em 1972 a Instituta Adalfo Lutz adatau o procedimento de semear o líquido cefaloráquidiano imediatamente após a cD lheira, em meios de cultura apropriados, mantendo-os em estufa até o transporte para o laboratório, o que permitiu o aparecimento de maior número de culturas positivas.

D que chama a atenção é a alta letalidade por meningite de causa indeterminada, fato de dificil explicação. Dutra fä to para o qual também não encontramos explicação é o des créscimo repentino dessa letalidade no $1^{0}$ semestre de 1974 , ao contrário do que aconteceu com as meringites meningocócio日s.

3. Distribuição cranoiógica dos casos

A maior incidência da moléstia nos meses frios encontrada na atual epidemia, já é referida desde os primeiro estudos epidemiológicos da moléstia (11) (58) e é abservada nos pe ríodos endêmicos e epidêmicos. É relacinada à possibilida de de maior transmissão de meningococo pelo confinamento de pessoas em ambientes fechados, assim camo pela acarrên cia mais freqbente de afecçães respitatórias virais que , através de sua sintomatologia característica, facilitariam a eliminaçãa das bactérias do nasofaringe。Um sinergismo de ação entre virus a a meningococo no hospedeiro, pode também ocorrer。Eichenwald (22) obgervou que a colonização no nasofaringe de recém nascidos por bactérias (estafiloco cos, pneumococos, estreptococos), fai significativamente fa 
cilitada pela simultânea infecção viral, e tenta explicar essa interação virus-bactérias por uma depressãa nas defé $8 a s$ locais provocada pelo virus. Um mecanismo semelhante poderia ser congiderado em relação à colonização do menin gococo.

Goldstein e colaboradores (1972). (34) verificaram experi mentalmente em ratos que uma infecção por vírus deprime a pós um e quatro dias a atividade bactericida meningocócica pulmonar dos animais. O valor dessa investigação em rele ção 80 homen é especulativo.

Há um relato publicada por Levitt e colaboradores (1970) (51), da ocorrência simultânea de meningite meningocócica e meningite por virus Echo-9.

Young e colaboradores (1972) (72) falam nesse sinergismo , deacrevendo a ocorrência simultânea de meningite meningocó cica e influenze em uma comunidade fechada.

\section{Distribuição geográfica dos casos}

Não se abservau na epidemia atual de São Paulo maior incí dência dos casos nos locais de maior densidade populacio nal. No entanto, há uma tendência para atingir as éreas ande residem as pessoas de menor pader aquiaitiva, marando provavelmente em condiçães de maior aglomeração habitacional. A observação de maior morbidade nos locais de maior 
número de moradias com superpopulação, já fai feita em iṇ́ meros trabalhos.

Em Baltimore (4D), em um estudo realizada durante duas epí demies de meningite meningocócica, de 1935-1937 e 1941-1942, relacionando as coeficientes de morbidade em áreas cam di ferentes parcentagens de maradias super-habitadas (definides como aquelas com mais de 1,5 pessoas por aposenta), ve rificau-se um evidente aumento dos coeficientes de marbida de a medida que as áreas apresentavam maior porcentagem deg sas moradias. Pizzi (55) no Chile, durante a epidemia de 1941-1942, observou uma correlaçãa evidente entre as main res taxas de casos secundários familiares e a maior aglome ração habitacional.

Kaiser e colaboradores (1974) (44) па Flórida,durante uma pequena epidemia da maléstia, observaram uma correlaçãa significante entre o número de pessoas que dormiam no mes mo quarto e a proporçãa de portadores de meningite.

Têm sida abservadas altas taxas de portadores entre as pes soas que residem junto com as daentes, assim cama a ocor rência de casos secundários entre essas pessoas. Pouco se conhece, no entanta, sobre os padrões de disseminação da infecção entre esses camunicantes próximos.

Greenfield e Feldman, em 1966 pesquisaram em Syracuge, New York, portadores entre os familiares e contactos primáriog 
(pessoas que tiveram contato com as doentes durante o pe ríodo de incubação) de três doentes de uma mesma família。 Encontrarm 11 portadores entre os 25 familiares (44\%) e 12 portadores entre as 60 contactos primários (20\%)。 Investi gações realizadas no mesmo local em três grupos populacin nais que não haviam tido contacto conhecido com doentes de meningite meningocócica mostraram taxas de portadores infe riores a 3\%。

Munford e colaboradores (54) realizaram em 5ão Paulo, em outubra e novembro de 1972, uma pesquisa de portadores do meningococo sorogrupo C entre pessoas que viviam na mesma casa dos doentes, pessoas que viviam nas vizinhanças e pes soas que não tinham tido aparentemente nenhum contacto com 08 doentes.

Verificarm os autores uma parcentagem de portadores mais alta $(14,2 \%)$ entre as que tinham tida contato com um doen te de meningite meningocócica do que entre as que não tị nham tido contato algum $(3,6 \%)$. Entre os que tinham tida contata com um doente, a porcentagem de portadores era mai or entre as pessoas que dormiam na mesma casa(17\%)da que en tre as: que visitavam o doente ou trabalhavam com ele $(3,2 \%)$. As porcentagens de portadores foram mais altas nos residen tes em uma casa em que o daente fasse um latente (37,8\%), intermediárias nos residentes com um doente de 1 a 14 anos de j.dade $(17,5 \%)$ e mais baixas nos residentes com um doen te adulto $(6,9 \%)$ 。 
Casos secundários ocorreram no mesmo endereço em 2,6\% dos casos de crianças de 1 a 4 anos, e em $0,2 \%$ dos 320 casos de adultas. Nenhum casa secundária ocorreu nos 179 casos de latentes.

Qs resultados desses estudas confirmaram a hipótese de que a infecção meningocácica é usualmente introduzida na famí lia pelos adultos, propagando-se subsequentemente aos 므 tros membros da família e atingindo os latentes depois que há uma densidade de infecção familiar relativamente alta。

Schmid e Galvão (62), estudando a epidemia de 1945-1951 ח Município de 5ão Paula, já haviam observado uma relação in versa entre morbidade e densidade demográfica e explicaram - fato pela possibilidade de maior aglomeração habitacional nos locais de menor densidade demográfica.

$\mathrm{Na}$ atual epidemia de meningococo grupo $\mathrm{C}$, os distritos sa nitários que apresentaram maior morbidade foram as de Sen to Amaro, São Miguel e Lapa. São justamente og distritos sanitários do Município de menor densidade demográfica.

Nos primeiros dois meses da epidemia de meningococo grupo A, a maioria dos casos se concentrau nos distritos da Lapa, Butantã e Santo Amaro, limîtrofes do município de Osasca, onde provavelmente eclodiu a epidemia. 
5. Distribuiçãa dos casos segundo a iddade

A distribuição etária dos casos, no períndo pré-epidêmi co de 1968-1970 e epidêmico de 1971-1973 mostra que são mais atingidos pela maléstia os latentes e crianças até 14 anos. Esses dados estão de acorda cam a conhecimento que se tem sobre a imunidade natural à moléstia, iniciada e refarçada no transcorrer da vida pelas intermitentes colonizações no nasofaringe de diferentes cepas de meningococos, patogênicos ou กão. (30) (31). A elevação do título bactericida ocorre dentro de duas semanas apás o início do estado de portador. Essa imunidade, que é maior no nascimento, pela transferência passiva de anticorpos IgG da mãe para o fe to, decresce e se torna menor dos 6 ans 24 meses, havendo após essa idade um aumento progressivo de aproximadamente 5\% ao ano no número de crianças que possuem atividade sérí ca bactericida contra estirpes de menịgococos patogênicos (31)。

Em 1974, com o aparecimento da epidemia de meningococo grL్ po $A$, há um aumento proporcionalmente maior dos casos no grupo etário de 15-39 anos.

Analisando-se a distribuição dos casos no primeira mês em que fai evidenciada a epidemia por meningococo grupo C, ve rifica-se que a grupo etário mais atingico fai a de laten tes, e que $77 \%$ dos casas tinham menos de 14 anos. Parece evidente que havia uma alta proporção de adultos portado res responsáveis pela transmissão intra-familiar da molég 
tia a esses latentes. No entanto pressupõe-se que esses adultos, se não apresentaram a forma sistêmica da moléstia, possuiam um certo nível soralógico de anticarpos anti-menin gocócicos grupo C。

No primeiro mês em que foram verificados casos de meningi te meningocócica grupo $A$, as adultas jovens foram muito a tingidos (37\% tinham 15 a 24 anos). Nãa houve nenhum caso entre as latentes e uma porcentagem pequena no grupo de 1 a 4 anos, evidenciando distribuiçãa etária dos casas dife rente do que caracterizou a início da epidemia de meninga coco grupo C. Maior proporção dos indivíduos inicialmente mais expostos apresentou a forma sistêmica da moléstia. o que determinou essa menor defesa an meningococo tipo A? SEe ria essa bactéria dotada de maior virulência? Teria sida subitamente introduzida na população, importada de outro local?

Essas hipóteses nos parecem viáveis pois, em 3 anas de ex tensa epidemia causada pelo meningococo sorogrupo C, a Pㅁ pulação adulta, mais exposta, teria tido oportunidade de desenvalver uma certa imunidade natural ao meningococo sㅁ ragrupo A. A antigenicidade cruzada entre as diversos sㅁ rogrupos foi demonstrada pelos trabalhos de Goldschneider e colaboradores (31) e Jennings e colaboradores (42). 
A maior virulência da bactéria no entanto, explicaria esse maior número de casos de moléstia sistêmica na população inicialmente mais exposta.

Qutra hipátese é que a populaçãa adulta inicialmente atin gida fosse constituida por indivíduos que tivessem migrado recentemente para a Município de Sãa Paulo.

De qualquer forma, a tendência da epidemia de meningococo A será deslocar-se progressivamente para as idades menares. reproduzindo o comportamento intra-familiar observado por Munford em seu trabaliho sobre portadores, realizado em São Paula em 1972 ( 54 ).

Na epidemia de meningite meningocócica ocarrida no Municl pí de São Paula, de 1945-1951, Schmid e Galvão (62) obseI varam maior acometimento no grupo etário de 15 a 19 anos. Nessa ocasião não fai feita a sorotipagem do meningococo causador da epidemia, mas Morais e Feldman (53) acreditam que tenha sida a soragrupo A, pois na mesma acasião 19411942, ocorreu violenta epidemia no Chile, determinada por esse sorogrupo.

6. Distribuiçãa dos casos segundo 므 sexo

0 maior acometimento do sexa masculino tem sida verificado e é relacionado à maior oportunidade de contágio, não pare cendo existir uma predispasiçãa orgânica diferente nos 
dois sexas. Moraes e Feldman (53) lembram que as epide mias da moléstia em civis frequentemente seguem epidemias em grupos militares e a maior númera de casos entre hamens seria explicável pela contato das jovens com seus amigos militares (роr exemplo, as epidemias de 1917-1918 e 19411945 nos Estadas Unidos). Esse argumento não encontra 旦 pala na casa atual, uma vaz que não houve surta epldêmico em nenhum das quartéis militares do Município。

Altmann e colaboradores (1973) (1) fizeram interessante ob servação em Israel sobre a incidência de infecções meningo cócicas assintomáticas em grupos de recrutas militares mag culinos, femininos, e em alunas de enfermagem, todos cong tituidas de jovens de 17 a 18 anos, provenientes de várias localidades do país. A incidência de infecção foi de 78,8\% e 86,2\% entre os recrutas masculinas, 63,5\% entre os recru tas femininos, e $21,2 \%$ entre as alunas de enfermagem. Se gundo os autores, torna-se difícil deduzir que a sexa mas culina fosse mais suscetível a maléstia pais diferiram nos tres grupos e tipo de alojamento usada e a intensidade do exercício e stress a que foram submetidos. Ds recrutas masculinos foram alojados em tendas de $57 \mathrm{m3}$ de volume, 10 a 12 homens por tenda, submetidos a vigorosa atividade fígi ca durante o períada de abservaçãa. Os recrutas femininos foram alojadas em uma grande barraca com uma distância de 60 a $80 \mathrm{~cm}$ entre as camas e foram submetidas a exercícios físicos de menor intensidade que os recrutas masculinos. 
Finalmente, as alunas de enfermagem foram alojadas na Escola de Enfermagem, duas alunas em cada dormitório, e não f므 ram submetidas a atividade física intensa.

Em relação ao Município de 5ão Paulo, se compararmas os coeficientes de morbidade no sexa feminina durante as epi demias de meningite meningocócica de 1945-1951 (62) e as epidemias atuais abservamos que o sexa feminino foi mais atingido na última epidemia, o que poderia ser explicada pela maior exposição, uma vez que vem aumentando gradative mente a númera de mulheres que trabalham fara do laro

7. Distribuiçãa cronológica da letalidade

A letalidade mostrou um decréscima cam a evoluir das anos, explicável pelas melhores condiçães de diagnástica, atendi mento hospitalar e arsenal terapêtico. A menor letalide de nos períndos epidêmicos pode ser relacionada à maior atenção da população e classe médica para o problema, pog sibilitando diagnástico e tratamento precoces.

No entanto, Freyche (27) observanda esse decréscima da le talidade nos períndos epidêmicos, atribui a fato a um a mento proporcionalmente maior de casos mais brandos em re lação aos casos graves e fataiso

Em 1974 há uma elevação na letalidade。A grande sobrecạ ga a que a Hospital Emília Ribas fai submetida pelo consi 
derável aumento de casos determinada pela epidemia causa da pelo meningococo A. podem explicar essa elevaçãa.

Em julho desse ana, a Hospital chegou a ter cerca de 1.046 doentes internados (*) (sua capacidade é para 450 leitos), antes que fasse ampliada a rede hospitalar de atendimento à meningite.

A variação sazonal de letalidade em sentido oposto à morbî dade, que ficou evidenciado no perílodo epidêmico, é um fä to de muito importância para as autoridades sanitárias.Nas meses de verãa, em que a morbidade diminuiu, a letalidade se elevou, o contrário ocorrenda nos meses de inverno. Des sa forma, é errônea a avaliaçãa da evolução da epidemia pe los dados de letalidade. No entanto, nas notícias publica das diariamente pelos jornais observa-se uma ênfase nos de dos de letalidade que, de uma farma indireta, informam tam bém à população sobre as condiçães de atendimento médicohospitalar. Porisso é importante o esclarecimento de que está ocorrendo uma variação sazonal dessa letalidade, fato já evidenciado por Freyche em um trabalho publicado em 1951 (27)。

(*) Informação do Dr. Carlos de Oliveira Bastos, Diretor do Hospi tal Emilio Ribas, em aula proferida em 1974, na Faculdade de Saúde Pública, Mo Curso de Administração Haspitalar。 
Não encontramos uma expliceção clara para esea fato. A in cidência de casas de meningococemia, que apresentam uma letalidade maior, não fai significantemente diferente nos meses frios e quentes. Parece provável a explicação de Freyche (27) de haver nos meses frios aumento proporcional mente maior de casas mais brandos em relação aos casos grạ ves e fatais.

4. Distribuição da letalidade segundo a idade Os grupos etários extremos foram as que apresentaram maior letalidade, fato já evidênciado em outras moléstias infeç ciosas e explicável pelas menares condições de defesa argâ nica desses grupos.

9. Digtribuição de letalidade segundo 므 gexo Dcorreu letalidade maior na sexa masculina, fato também presente consideradas separadamente as meningococemias a as meningites meningococicas. Não encontramos explicação para isso. A maior possibilidade de exposiçãa ao meningo coco e a estafa física podem explicar a maior morbidade da moléstia no sexa masculino. Haveria um fator constitū cional ligado ao sexo que determinaria a maior letalidade? 


\section{VIII - CONCLUSUES}

1 - As últimas publicaçães mundiais indicam que a imunização da população suscetível com a vacina polissacaride meningocócica pare ce sвr a melhor medida profilática dispanível contra a moléstia me ningocócica, ao lado de diagnóstico precoce e adequada assistência médico-hospitalar aos doentes.

2 - As migrações populacionais para a Grande São Paulo podem ter contribuido para desencadeer as epidemias de meningite meningocócí ca de 1971 a 1974 na área, e seria oportuna uma investigação nesse sentido.

3 - Ds caracteres epidemiológicos das duas epidemias, no Municí pio de 5ão Paulo, dependeram das candiçães climátices, da maior aglomeração habitacional, da maior possibilidade de exposição ao meningococo e do estado imunológica específico da população. Dco工 reu maior incidência de casos da maléstia nos meses de temperatura mais baixa, nas áreas periféricas do Município, no sexo masculino e no grupo etário de 0 a 4 anos.

4 - No início da epidemia determinada pelo meningocaco soragrupo C, o grupo etário mais atingido pela moléstia fai o de 0 a 4 anos. No infcio da epidemia causada pelo meningococo grupa $A$, foi a gru po etário de 15 a 24 anos. A maior vitulência do meningococo soro grupa A e sua intradução repentina na populaçãa podem explicar es se fato. 
5 - A letalidade vem apresentando um decréscimo progresaivo, atrí bufvel a melhores candições de disgnóstico, atendimento hospitalar a medicação. Esea letalidade fol menor no período epidêmico de 1971-1973, em relaç̃o ao perfodo pré-epidêmico de 1968-1970, proven velmente pela meior atenção da classe médica e da população à doen ça. Ocorran elevaçõo da letalldade no 10 gemegtre de 1974 , expli cável pelas condiçōes de gabrecerga a que fol submetido o Hospital Emfilo Ribas, para onde eren enceminhados $50 \%$ dos doentes.

6 - Durante o perfodo eplốmico a letalidade apresentau uma va riação sazonal, no sentido inverso ì morbidade. Nos meses frios ocorreu uma diminuiçãa da letalidade e nos meses quentes um aumen to de mesme.

7 - Para um estudo epidemiológico mais fidedígno da meningite me ningocócica em São Paulo é importante que melhore a notificação de casos por médicos e hospitals particulares ao 5erviço de Epidemio logia da Divisão Reggional de Saúde da Grande São Paulo, a que nesse Serviço se rẹgistrem a computem os dados atravís de proces sos mais modernos que permitain um levantamento mais rápida e mais detalhada. Também não leta senda feita claseificaçãa socio-econâmica dos daentes possibilitando um estuda nesse sentido com vistas a uma aplicação administrativa. Da mesma forme, é recomendável mel or atenção dos clínicos ìs condições de colheita, manutenção e transporte do liquida cefaloraquidiano, aseim como ao uso indiscri minado de antibióticos. Esse procedimento possibilitaria uma me lhora no diagnóstico laboratorial da meningite meningocócica. 
0 autor fez um estuda epidemialógico sobre a meningite menin gocócica no município de São Paulo durante o períado de janeiro de 1971 a junho de 1974.

Durante esse período duas epidemias da moléstia ocorreram na área estudada. A primeira se iniciou em julho de 1971 e fal causa de pelo meningococo sarogrupo C. Ds primeiros casos da segunda e pidemia, determinada pelo meningococo sorogrupo $A$, foram observa dos em abril de 1974, ocasião em que a primeira epidemia ainda não havia terminado. D número total de casos confirmados notificados ao Departamento Regional da Saúde da Grande 5ão Paulo fai de 4.431.

Os maiores coeficientes de morbidade faram abservadas: duran te as meses frios; nos distritos sanitários da periferia do municí pio, ande vive a população de menor poder aquisitivo; nos latentes. Durante as dois primeiras meses das duas epidemias, houve uma dife rença significante nos grupos etários mais atingidos pela moléstia. Enquanto na primeira epidemia o grupa dos latentes foi mais atingi do, na segunda epidemia grande númera de casos ocorreu entre os adolescentes e adultos jovens (15-24 anos).

A letalidade decresceu de 15,0\% durante o período pré-epidêmico de 1968-1970 para 7,9\% no períado epidêmico de 1971-1974. Foi observeda uma variação sazonal da letalidade no sentido inverso ao da morbidade.

0 autor considera que as migrações populacionais passam ter representado um papel importante na eclosãa das epidemias e sugere uma investigaçãa futura nesse sentida.

No inicio do trabalho foi feita uma revisão bibliográfica sa bre vacinação antimeningocócica, uma vez que a mesma parece ser o meio mais eficaz para a profilaxia da moléstia, ao lado de diagnó tico precoce e adequado atendimento médico-hospitalar. 


\section{SLMMARY}

The author has made an epidemological study of meningococal meningitis in the municipality of Sãa Paula, Brazil (population in 1970 - 5.931 .935 inhabitants) during the period ranging from fanuary 1971 to june 1974.

Two outbreaks of meningococal meningitis occurred during this period in the area under study. The first one began in july 1971 , due to serogroup C neisseria meningitidis; the second one began in april 1974, when the first outbreak wasn't yet finished. It was caused by serogroup $A$ neisseria meningitidis.

The total number of cases reported to Great São Paula Health Department through the time of the investigation; was 4.431.

The attack rates were higher during the colder manths. Peripheric districts, where a population of lower sacial class lives, had the majority of the cases. Infants were at greatest risk. There was, however, significant difference in the age of groups affected by the disease in the first month of both epidemics.

The group of infants was more affected in the first epidemic than in the second where the disease accurred mostly among adolescents and young adults ( 15 to 24 years).

The case-fatality ratios (deaths/cases) decreased firom 15\% (pre-epidemic period of 1968-1970) to 7,9\% (epidemic period of 1971-1974). There was a seasonal variation in the case-fatality ratio during the epidemic period: in colder months it decreased and in hatter months it increased.

According to the author, the internal population migrations may have played a significant part in causing these epidemics and an investigation in this respect may throw a new light on the problem.

Before starting her survey the author did a bibliographic revision on the subject of antimeningococcal vaccination, since it seems to be the most effective way far the prevention of the disease, together with an early diagnasis and adequate medical and hospital assi stance. 
IX - REFERÊNCIAS BIBLIOGRAFICAS

1 - ALTMANN, G. at al. Dbservations on asymptamatic infections with neiseseria meningitidis. Am. J. Epidemiol., 照:446-52, 1973.

2 - ARtenstein, M. et al. Prevention of meningococcal disease by group C polysaccharide vaccine. New Eng. J. Med., 282:417-20, 1970.

3 - ARTENSTEIN, $M$. et al. Cutaneous reactions and antibody response to meningococcal group $C$ polysaccharide vaccenes in men. J. Infect. D18., 124:372-7, 1970.

4 - ARTENSTEIN, M. et al. Serologic studies of meningoccal infection and polysaccharide vaccination. J. Inféct. D18., 124:277-88, 1971.

5 - ARtenstein, M. et al. Meningococcel infections. 1. Prevelence of esrogroups causing disease in U.5. Army personnel in 1970-74. Bul1. Org. mand. Santé., 45:275-8, 1971.

6 - ARtenstein, M. et al. Meningococcel infections. 3. Studies of group $A$ polysaccharide vaccines. Bull. Org. mond. Santé., 45: $287-90,1971$.

7 - ARTENSTEIN, M. Meningococcel infections. 4. 5tability of group $A$ and group $C$ polysaccharide vaccines. Bull. Org. mond. Santé., 45: 287-90, 1971 .

8 - ARTENSTEIN, M. Meningococcal infections. 5. Duration of polysaccharlde vaccine induced antibody. Bull. DIg. mand. Santé., 45:291-3, 1971 .

9 - ARTENSTEIN, M. et al. Immunoprophylaxis of meningococcal infection. Milit. Med., 129:91-5, 1974. 
10 - ARtenstein, M. Development and use of meningococcal vaccinea. Arch. Roum. Path. exp. microbiol., 33:127-32, 1974.

11 - ASSUMPC̄Ã, L. Estuda epidemialógico e bacteriológica da menin gite cerebroespinhal epidêmica na cidede de São Paulo. Rev. Bial. Hyg., 2:5-33, 1929.

12 - BARRETO, J.B. Tratado de higiene. 3a. edo Rio de Janeiro, Ateneu, 1956. p.493-512.

13 - BAstos, C.0. et al. Meningites: consideraçães sobre 15.067 ce sos internedos no Hospital Emílio Ribes, durante o quinque nid 1958-1972. Rev. As8. med. bras., 19:451-6, 1973.

14 - BIER, 0. Bacteriologia e imunologia. 13a. ed. 5ãa.Paula, Ed. Melhoramentos, 1966. P.398-402。

15 - BRANDT, B. et al. Antibody responses to meningococcal polysaccharide vaccines. Infect. 1mmun., 으:590-6, 1973.

16 - BRASil. Miniatório de Saúde - Meningite meningocócica. Bal.de Epidem. , 2:61-7, 1974 .

17 - DEPARTAMENTO INTERSINDICAL DE ESTATÍSTICA E ESTUDOS SDCIO ECD NÔMICOS. Nível alimentar da população trabalhadora da cidade de 5ão Paulo, 1973. (Estudos sacioeconamicas, v.l, n.1).

18 - DEVDE, I. \& GILCHRIST, J.E. Releses of endotoxin in the form of cell wall blebs during in vitra growth of neisegria meningi tidis. J. exp. med., 138:1156-67, 1973。

19 - DIAMENT, A. Meningites. In: MACHAdo, P. de A. Pediatria basica. 2a. ed. Sã Paula, Savier, 1968. p.5it7-59.

20 - DINGLE, J.H. Meningococcal disease. In: BeESON \& MC DERMOTT. Textbook of medicine. 12a. ed. Philadelphia, Saunders, 1967. p.190. 
21 - DUCKER, T. \& SIMMONS, R. The pathogenesis of meningitis. Arch. Neural., 18:123-8, 1968.

22 - EICHENWALD, H. et al. Some effects of viral infection on aerial dissemination of staphylococci and on susceptibilit! to bacterial colonization. Bact. Rev., 25:274-81, 1961.

23 - ERUA, H. et al. A serogroup A meningococcal polyseccharide vaccine studies in the Sudan to combat cerebrospinal meningiti caused by neisseria meningitidis group $A$ 。 Bul1. Qrg. mand. Santé., 49:301-5, 1973.

24 - FELdMANN, R. Las bases para la vigilancia de la meningite menj gococica. Rio de Janeiro, OPAS, 1973. (Apresentado ao Semina rí Regional sobre Sistemas. de Vigilância Epidemiológica de Enfermidades Transmissiveis e Zoonosis, Rio de Janeiro, 1973 DOC. $\Pi^{\text {Q 28) }}$

25 - FINLAND, M. (Editarial) Revival pf antibacteria immunization. Meningococcal vaccines prove promising. J. infect. Dig., I21:445-8, 1970 .

26 - FRASER, D。 et al. Risk factors in bacterial meningitis. Charleston Country, South Carolina. J. Infect. Dis., 127:271-7, 1973 .

27 - FREYCHE, M. Repartition et evalution de la meningite cérebrospinale dans le monde depuis 1939. Rapp. epidém. démog., 4: $311-31,1951$.

28 - Fundação IBge. Censo demagráfico de 1970: Estado de São Paulo. Rio de Janeiro, 1970.

29 - GOLD, R. \& ARTENSTEIN M. Meningococcal infections. 2. Field trial of group $C$ meningococcal polysaccharide vaccine in 1969-70. Bull. Org. mand. Santé., 45:279-82, 1971. 
30 - Goldschneider, I. et al. Human immunity of the meningococcus. II. Development of natural immunity. ]. exp. Med., 129: $1327-48,1969$.

32 - GOLDSCHNEIDER, I. et al. Immunogenicity of the group $A$ and group $C$ meningococcal polyssacharides in children. ‥ infect. Dis., 125:509-19, 1972.

33 - GDLDSCHNEIDER, I, et al. Immunggenicity of group $A$ and group C meningococcal polysaccharides in human infants。 J. infect. Dis., 128:769-76, 1973.

34 - GOLDSTEIN, E. et al. Murine resistance to inhaled neisseria meningitidis after infection with an encephalo myocarditis virus. Infect. immun., 6:398-402, 1972.

35 - GOTSCHLICH, E. et al. Human immunity the meningococcus. III. Preparations and immunochemical properties of the group $A$, group $B$ and group $C$ meningococcal polysaccharides. J. Exp. Med., 129:1349-64, 1969.

36 - GOTSCHLICH, E. et al. Human immunity the meningococcus。 IV. Immunogenicity of group $A$ and group $C$ meningococcal polysaccharides in human valunteers. J. exp. Med., 129: 1367-84, 1569.

37 - Gatschlich, E. et al. Human immunity to the meningococcus. $V$. The effect of immunization with meningococcal graup $C$ polysaccharide on the carrier state. J. exp. Med., 129: 1385-95, 1969.

38 - GOTSCHLICH, E. et al. The immunological responses abserved in field studies in Africa with group A meningococcal vaccines. Prog. immunobiol. Stand., $\underline{5}: 485-91,1972$ 。

39 - GREenfield, 5. \& FELDMAN, H. Familial carriers and meningococca. meningj tis. New Engl. J. Med., 277:497-502, 1967. 
40 - HEDRICH, A. Recent trends in meningococcal disease. Publ. H1th. Rep., 67:411-20, 1952.

41 - HEIST, G. et al. A study of the virulance of meningacocci far man and human susceptibility to meningococcus infection. J. Immunol., 2:1-33, 1922.

42 - JENNINGS, H. et al. Cross protective antigens of neisseria meningitis obtained from slaterus froup $Y$. Infect. Immun., 5:547-51, 1972 .

43 - JUNQUEIRA, M. Meningite cerebromespinhal a meningococus - Con tribuição para sua epidemiologia. An. paul. Med. Cirurg., 2: $46-63,1914$.

44 - KaISER, A. Seroepidemiology and chemoprophylaxis of disease due to sulfonamide resistante neisseria meningitidis in a civilian population. ‥ infect. Dis., 130:217-24, 1974.

45 - KASPER, D. et al. Antigenic specificity of bacteridal antibodies in antisera to neisseria meningitidis. J. Infect. Dis., 127:78-387, 1973.

46 - KNIghts, H.T. Meningococcal Meningitis in New Zealand with special reference to carrier rates in military trainees. N. Z. med。, 76:16-21, 1972 .

47 - Lapeyssonnie, L. La méningite cérebro-spinale en Afrique. 昂11. Org. mond. Santé., 28 (suppl.):1-114, 1963。

48 - LAURenti, R. Causas multiplas de óbito. São Paulo, 1973. Tese de Livre Docencia - Faculdade de Saúde Pública - USP

49 - LESER, W. \& BARBOSA, V. Relacionamento de certas característị cas populacionais cam a mortalidade infantil no município de São Paula, de 1950 a 1970. Problemas Brasileiros. 10(109): $17-33,1972$. 
50 - LiMA, C. Meningites bacterianas em 5ãa Paula. An. Paul. Med. iㅗㄴㅗ., 24:145-9, 1932.

51 - LEVITT, L. et al. Meningococcal and Echo-9 meningitis report of an outbreak. Neurology., 20:45-51, 1970。

52 - MONTO, A. et al. Response of children to neisseria meningitidis polysaccharide vaccines. ‥ infect. Dis., 128:194-200, 1973.

53 - MORAES, J.5. et al. Epidemic disease due to seragraup C neisseria meningitidis in 5ão Paula, Brazil. J. infect. Dig., 129: 568-571, 1974 .

54 - MUNFORD, R. et al. Spread of meningococcal infection within households. Lancet., 1:1275-78, 1974.

55 - PIZZI, M. A severe epidemie of meningococcus meningitis in Chile, 1941-1942. Amer. J. publ. Hlth., 34:231-8, 1944.

56 - RELLER, L. et al. Bactericical antibody after colonization with neisseria meningitidis. J. infect. Dis., 127:56-60, 1973.

57 - RILEY Jr., H. Meningococcal disease and its contral. Sth. med. J., 66: $107-14,1973$.

58 - ROSENAU, M.J. \& MAXCY, K.F. Preventive medicine and public health. 9a. ed. New York, Appleton-Century-Crofts, 1965.

59 - SANBORN, W. et al. Trial of a serogroup A meningococcus polysaccharide vaccine in Nigeria. Prog. immunobial. Stand., 5: 497-505, 1972 .

60 - SÃo PaUlo (Estado) Secretaria de Economia e Planejamento. GEGRAN. Diagnóstico da primeira Reqiãa Administrativa da Estado de São Paulo. São Paulo, 1973. 
61 - SẮ PAULO (Estado) Secretaria de Economia e Planejamento.

Departamento de Estatística. População por regiões adminis trativas do Estado de 5ãa Paula - 1970-1972 (Mimeografada).

62 - SCHMID, A. \& GALVÃO, A.A. Alguns aspectos epidemiológicos da meningite meningocácica no Município de 5ão Paulo. Afg. Hig., São Paulo, 26:15-39, 1961.

63 - SERrÉ日otSSEAL, F. La méningite a meningocoques in France 1968 a 1972. Bull. Org. mand. Santé., 48:675-83, 1973.

64 - SoboLL, M.L. Diferenciais socioeconômicos dos migrantes asea larladas Iegidentes na cldade de São Paulo. São Paula, 1974. Monografia de Mestrado - Faculdada de Saúda Pública USP.

65 - TAUnay, A.E. Profilaxia da meningite meningocócica. J. Aag. méd. braa., 16: (720):6, 1974.

66 - TRAMONT, E. \& ARTENSTEIN, M. Latex agglutination test for measurement of antibodies to meningococcal polysaccharides. Infect. Immun., 5:346-51, 1972.

67 - TRIAU, R. Méningite cérebro-gpinale et vacination antiméningo cocique. Prog. 1mmunabiol. Stand., 5:454-71, 1972.

68 - VIGILANCIA epidemiológlca e controle de meningite cerebro-eg pinhal na Africe. Cran. Org. mund. Salud., 27:375-80, 1973.

69 - WAHDAN, M. et al. A controlled field trial of a serogroup $A$ meningococcal polysaccharide vaccine. Bull. Wld HItd $\mathrm{DI}_{I}$., 4으:667-73, 1973.

70 - WENZEL, R. et al. Antigenicity of a polysaccharide vaccine from neisseria meningitidis administred intranasally. J. Infect. Dis., 128: $31-40,1973$. 
71 - WILSON, F. \& MILES, A. Principles of bacteriology and immunity. 5a. ed. Londan, Arudd, 1964. P.1736-49.

72 - YOUNG, L. A simultaneous outbreak of meningococcal and infiluenza infections. New Eng1. J. Med., 287:5-9, 1972.

73 - ZOLLINGER, W. et al. Isalation and characterization of a native cell wall complex from neiseria meningitidis. Infect. Immun., 6: $835-51,1972$. 